\title{
Judicial Review of the Administrative Record in NEPA Litigation
}

\author{
Susannah T. French $\dagger$
}

Judicial review of administrative decisionmaking must strike a balance between allowing agencies to have adequate power to perform their duties and ensuring that agencies follow the law. In deference to administrative autonomy, courts have adopted a "record rule," refusing to consider evidence that was not first presented to the agency. In this Comment, the author argues for an exception to the record rule when courts review agency action under the National Environmental Policy Act (NEPA). NEPA requires all federal agencies to analyze the environmental impacts of their projects, but their failure to prepare a complete analysis is often not apparent from the record. The author also argues that the policies underlying the record rule-including the presumption of administrative expertise, concerns about judicial intrusion into agency independence, reliance on public input to ensure an adequate record, and worries about plaintiff sandbagging-are less compelling in the context of NEPA litigation. Furthermore, the agency's duty to gather relevant information should be independent of the degree of outsider participation in the administrative process, especially given the limited resources of the public interest group plaintiffs that generally bring NEPA suits. Lastly, the author briefiy examines whether the principles behind the NEPA exception may be extended to other areas of judicial review of administrative actions.

\section{INTRODUCTION}

The explosion of admmistrative decisionmaking in the twentieth century has demanded the creation and continual refashioning of a new body of law. ${ }^{1}$ Administrative agencies exercise a broad range of powers

$\dagger$ A.B. 1988, Harvard University; J.D. 1993, Boalt Hall School of Law, University of California, Berkeley.

I would like to thank Niel Lawrence for helping me formulate many of the initial ideas behind this Comment, Professor John Dwyer for his persistent encouragement and his critical readings of numerous drafts of this paper, and Danny Cloherty and Anuj Desai for the clarity and care of their editing.

1. For perspectives on administrative law as it has developed through the 20th century, the following works are helpful: CHRISTOPHER F. EDLEY, JR., ADMINISTRATIVE LAw: RETHINKING Judicial Control of Bureaucracy (1990); Lou1S L. JAFFe, Judicial Control of Administrative Action (1965); James M. LAND1s, The Administrative Process (1938); and Richard B. Stewart, The Reformation of American Administrative Law, 88 HARV. L. REV. 1669 (1975). Robert L. Rabin's Federal Regulation in Historical Perspective, 38 STAN. L. REv. 1189 
and may serve as judiciaries, legislatures, or law enforcers. ${ }^{2}$ Unlike these other bodies, however, admimistrative agencies are presumed to have special knowledge $m$ the fields that they regulate. ${ }^{3}$ Thus, Congress generally has given agencies significant authority and discretion to use their expertise to serve the broader public good. ${ }^{4}$

The breadth of discretion granted by Congress, however, has not immunized administrative agencies from judicial review. The Administrative Procedure Act provides that the courts generally have the power to review the legality of administrative decisions. ${ }^{5}$ But while the judicial power to review administrative decisions is clear, courts have struggled to determme the proper scope of and limitations on this power in light of the Congressional recognition of agency expertise.

Judicial review of administrative decisions typically has been, especially at the Supreme Court level, highly deferential. ${ }^{6}$ When reviewing agencies' actions, courts have historically used the same criteria that appellate courts employ in reviewing district court decisions-the agencies are deemed to be the key fact-finders, while the courts focus on reviewing the legality of the their actions. ${ }^{7}$

(1986), provides a useful historical summary of American administrative law. Administrative law in the United States has beeu developed mostly through the common law. See Kenneth C. Davis, Administrative Common Law and the Vermont Yankee Opinion, 1980 UTAH L. REv. 3, 3.

2. See JAFFE, supra note 1, at 20-27.

3. See EDLEY, supra note 1, at 4, 54-57; Stewart, supra note 1, at 1678.

4. See EDLEY, supra note 1, at 5-6 (noting that "many statutes include a catchall delegation of substantive rule making authority to the agency, instructing the administrator to make any rules 'necessary' or 'appropriate' to accomplish the purposes of the statute"). The scope of this discretion has been somewhat narrowed since the 1970s, when Congress started passing statutes that placed more specific responsibilities and constraints on agencies. See MarTIN SHaPIRO, Who GUARDS THE GUARDIANS? JUdicial CONTROL OF ADMINISTRATION $78-81$ (1988); Rabin, supra note 1, at 1290-91.

5. 5 U.S.C. $\$ 702$ (1988). Judicial review of administrative decisions is available where "there is no indication that Congress sought to prohibit judicial review and there is . . no 'showing of "clear and convincing evidence" of a . . . legislative intent' to restrict access to judicial review." Citizens to Preserve Overton Park v. Volpe, 401 U.S. 402, 410 (1971) (quoting Abbott Laboratories v. Gardner, 387 U.S. 136, 141 (1967)).

6. See Richard M. Thomas, Prosecutorial Discretion and Agency Self-Regulation: CNI v. Young and the Aflatoxin Dance, 44 ADMIN. L. REv. 131, 131-33 (1992) (contrasting the Supreme Court's tolerance of admiuistrative autonomy with the D.C. Circuit's distrust of agency discretion); see also Chevron U.S.A., Inc. v. Natural Resources Defense Council, Inc., 467 U.S. 837, 844-45, 865-66 (1984) (accepting the long-held "principle of deference to administrative interpretations"); EDLEY, supra note 1, at 69-70 (noting that judicial deference to agency discretion reduces the quality of administrative action).

7. See Bernard Schwartz, Administrative Law § 10.2 (3d ed. 1991); see also Administrative Procedure Act, 5 U.S.C. $\$ 706$ (1988) (stating that "the reviewing court shall decide all relevant questions of law"). This is, of course, only a general rule. The application of law to facts in the context of judicial review of administrative agencies has been the subject of a great deal of scholarship. See EdLEY, supra note 1, at 29-36; Walter Gell horN ET Al., Administrative LAW 348-446 (8th ed. 1987); JAFFE, supra note 1, at 595-99 (discussing judicial review of questions of fact); LANDIS, supra note 1, at 123-55; id. at 592-94 (comparing Jaffe's view with that of Professors Davis and Landis); ScHWARTZ, supra § 10.5. 
Adhering to this deferential stance, courts have tended to apply what I will refer to as the "record rule." Under the record rule, courts refuse to consider evidence that was not first presented to the agency. ${ }^{8}$ Rather, review of agency action is limited to an examination of the record compiled by the agency at the time it made its decision. This record consists of the material the agency considered in reaching its final decision, including comments from other agencies and the general public. ${ }^{9}$ The record rule was developed to protect the integrity of agency decisionmaking and to spare courts from lengthy proceedings on highly technical matters. In practice, however, the rule has often proved unworkable and confusing, and courts have developed a number of exceptions to allow consideration of extra-record evidence, i.e., evidence that was never presented to the agency and thus is not contained im the agency's record. ${ }^{10}$ One of the most prominent exceptions that developed during the 1970s and 1980s was a judicial willingness to admit such extra-record evidence when reviewing agency action under the National Environmental Pohicy Act (NEPA). ${ }^{11}$

NEPA is a legislative act imtended to force agencies to consider the environmental impact of their projects. ${ }^{12}$ In order to comply with the statute's provisions, an agency must prepare documents that reflect the agency's consideration of these environmental factors. ${ }^{13}$ NEPA cases generally involve charges that an agency's preparation of documents required by NEPA for major federal actions-environmental assessments and environmental impact statements - has been inadequate.

Since the inception of NEPA, numerous courts, particularly after the Second Circuit's decision in County of Suffolk v. Secretary of the Interior, ${ }^{14}$ have allowed plaintiffs bringing claims imder NEPA to introduce new evidence. While the NEPA exception to the record rule has been widespread, it has never been umversally accepted. ${ }^{15}$ Several cir-

8. See Schwartz, supra note 7, § 10.2; Richard McMillan, Jr. \& Todd D. Peterson, The Permissible Scope of Hearings, Discovery, and Additional Fact-Finding During Judicial Review of Informal Agency Action, 1982 DUKE L.J. 333.

9. McMillan \& Peterson, supra note 8, at $340-43$.

10. See Steven Stark \& Sarah Wald, Setting No Records: The Failed Attempts to Limit the Record in Review of Administrative Action, 36 ADMIN. L. REV. 333, 344 (1984) (classifying the exceptions as applying where the agency did not adequately explain its action, the agency did not consider significant factors, the record does not reflect evidence that the agency considered, the issues are so complex that the court needs additional information to understand the case, new evidence arose after the agency's decision, the suit alleges the failure of the agency to act, the suit challenges the agency's action under the National Environmental Policy Act, and the suit involves a motion for a preliminary injunction).

11. 42 U.S.C. $\S \S 4321-4361$ (1988).

12. Id. $\S 4322(2)$.

13. $I d$.

14. 562 F.2d 1368 (2d Cir. 1977), cert. denied, 434 U.S. 1064 (1978).

15. See Daniel R. Mandelker, NEPA Law and Limigation $\S 4.09[1]$ (2d ed. 1992) (discussing NEPA cases both allowing and rejecting extra-record evidence). 
cuits tightly restrict the admission of extra-record evidence. Most notable of these is the Seventh Circuit, which recently challenged the NEPA exception and insisted that, barring an emergency, courts should review only the evidence presented to the agency during the administrative process. ${ }^{16}$ The Seventh Circuit's endorsement of the record rule has persuaded lower courts reviewing NEPA cases in other jurisdictions.

This Comment reviews the rationales for the NEPA exception and weighs them against the values behind the record rule. Part I discusses the history of the record rule as it has developed in the Supreme Court. This section considers the problems associated with building a record for informal agency actions, which include NEPA cases. While the Supreme Court has upheld the record rule as a general guideline, it has never fully explored the policy considerations behind the rule. In particular, it has never done so in the context of NEPA cases.

Part II exammes the requirements of NEPA and discusses the unique demands that the statute places on administrative agencies. This Part also considers the two limes of cases that have developed in the circuit courts, one allowing plaintiffs to present extra-record evidence in the district court and the other imsisting on judicial review based solely on the record before the agency.

Part III considers the application of the record rule in NEPA cases. This Part concludes that the NEPA exception is an appropriate judicial response to the unique nature of NEPA litigation. In NEPA cases, the agency's failure to include relevant information in the record is often the primary issue. In addition, the presumptions behind the record rule are often inapplicable. Because NEPA applies to all federal agencies, courts cannot presume agency expertise in predicting environmental impacts. Courts also ought be less concerned with intruding into the domain of agency independence, since NEPA does not grant them the ultimate authority to prevent an agency from proceeding with a proposed project. Nor should courts see the public comment periods required during the NEPA process as legitmizing the agency record. Finally, concerns about plaintiff sandbagging are best addressed by rules of exhaustion or of good faith rather than by the record rule.

Part IV examines the role of citizen and public interest groups in challenging NEPA decisions and the risk of passing agency duties onto outside groups. It concludes that plaintiffs must be able to introduce extra-record evidence in order to have a fair opportunity to challenge agency findings and ensure that NEPA's goals are met.

Finally, Part V uses the logic behind the NEPA exception to briefly discuss the factors that courts should look to in determining whether to accept extra-record evidence in non-NEPA cases.

16. Cronin v. U.S. Dep't of Agric., 919 F.2d 439 (7th Cir. 1990). 
The Comment concludes that, due to the unique structure of NEPA litigation, courts should allow the imtroduction of extra-record evidence to prove that a federal agency has failed to comply with NEPA's mandate. Courts conforming to a bright-lime record rule in NEPA cases niay be overlooking the important policies and rationales that aniniated the NEPA exception in the first place. A thoughtless or rigid application of the record rule would serve to undercut meaningful judicial review of agency action under one of the United States' most important environinental statutes. ${ }^{17}$

\section{I}

Judicial Review of AdMintstrative Agencies: A BRIEF INTRODUCTION

Judicial review of adnimistrative action inust strike a balance between allowing agencies to have adequate power and discretion to perform their duties and ensurmg that agencies follow the law. ${ }^{18}$ Courts must have some discretion to inquire into questions of legahity and should not beconie "nierely the judicial echo" of agency decisionmaking. ${ }^{19}$ However, in deference to presumed agency expertise and in recognition of the practical impossibility of judicial scrutiny of every administrative decision, courts have recognized the need to place limits on their review of agency action. ${ }^{20}$ The record rule is one such linit.

\section{A. The Historical Origins of the Record Rule}

The role of the courts in reviewing evidence was an issue in the first Supreme Court case involving judicial review of the first adninistrative agency. ${ }^{21}$ In Cincinnati, New Orleans \& Texas Pacific Railway Co. v.

17. A leading casebook on federal public land law asserts that "NEPA remains the most important procedural public land management statute [in the United States]" and comments that the "great majority of cases in this book that were commenced after 1970 have been premised at least in part on NEPA." George C. Coggins \& Charles F. Wilkinson, Federal Public LaND and RESOURCES LAW 321-22 (2d ed. 1987).

18. SCHWARTZ, supra note $7, \S 10.1$. Theories of the reach of judicial review of administrative decisions have not been static. Professor Robert Rabin, briefly summarizing the various movements in American administrative law, writes:

[1]t may be helpful to think of a continuum of interventionist strategies. On one extreme, judicial review could adhere to the model of de novo reconsideration, and in the Populist era the Supreme Court approached this polar extreme. In the post-New Deal era, by contrast, the Court moved to the other end of the continuum, adopting a strongly deferential model of review. Frequently, however, the Court oscillated between two intermediate points on the continuum ....

Rabin, supra note 1 , at 1193-94.

19. Universal Camera Corp. v. NLRB, 340 U.S. 474, 491 (1951).

20. See SCHWARTZ, supra note $7, \S 10.1$.

21. See id. $\S 10.2$ (discussing Cincinnati, N.O. \& Tex. Pac. Ry. v. ICC, 162 U.S. 184 (1896)). While Schwartz places this case in context, his suggestion that it establishes a "policy against [the taking of] evidence in the reviewing court," id., seems somewhat overstated. 
$I C C,{ }^{22}$ the Court expressed its concern that parties could sandbag an agency's mission by "withhold[ing] the larger part of their evidence from the [agency]" and later presenting such evidence to the court. ${ }^{23}$ Despite this concern, however, the Court explicitly rejected a strict rule of review based solely on the agency record, concluding, "We do not mean, of course, that either party, im a trial im the court, is to be restricted to the evidence that was before the [agency] . ..."24

In the early-twentieth century, as agencies began to play a larger role in determining private rights, the judiciary remained protective of its authority to supervise agency actions. ${ }^{25}$ The courts often reviewed agency decisions de novo and permitted parties to introduce new evidence and testimony. ${ }^{26}$ As the power of the agencies grew more established, however, the courts slowly began to grant increased deference to agency factfinding. In the 1910 case of ICC v. Illinois Central Railroad Co. ${ }^{27}$ the Supreme Court developed the now-familiar doctrine that courts were to decide questions of law, while granting deference to the agencies on questions of fact and policy. ${ }^{28}$

The record rule, forbidding the use of new evidence in judicial review of agency decisions, first appeared in 1930. In Tagg Bros. v. United States, ${ }^{29}$ the Secretary of Agriculture was required to determine whether a tariff of prices charged to buyers and sellers of livestock was "just and reasonable." 30 Noting that agency hearings on the matter had extended for "many months," 31 the Court held that allowing agency "findings to be attacked or supported in court by new evidence would substitute the court for the administrative tribunal as the rate inaking body." ${ }^{2}$ The Court concluded that, in cases where "important evidence was not brought to [tle Secretary's] attention," the appropriate reinedy was for the plaintiff "to apply for a rehearing before [the Secretary] or to institute new proceedings." 33

\section{162 U.S. 184 (1896).}

23. Id. at 196.

24. Id.

25. See JAFFE, supra note 1 , at $339-46$.

26. See Rabin, supra note 1 , at 1212-15.

27. 215 U.S. 452 (1910).

28. Id. at 470-71 (holding that the reviewing court may consider only whether the agency's decision was constitutional, reasonable, and within the scope of the agency's authority); see also Rabin, supra note 1, at 1234 (asserting that Illinois Central initiated the modern trend whereby the court decides only questions of law while deferring to the agency on questions of fact).

29. 280 U.S. 420 (1930).

30. Id. at 431 .

31. Id. at 432 .

32. Id. at 444. The Tagg Bros. Court also determined that an analogy existed between this case and the ICC cases, noting that the scope of review of the latter was limited by the Commerce Court Act of 1910, which provided that the Court must enforce all orders "regulariy made and duly served." Id. at 444 n.4.

33. Id. at $444-45$. 
The record rule continued to be recognized throughout the 1930s and early 1940s as an appropriate restriction on the courts' ability to interfere with the comprehensive investigatory missions of federal agencies. For example, in National Broadcasting Co. v. United States, ${ }^{34}$ the Court prohibited the imtroduction of evidence not presented to the Federal Communications Commission (FCC) during a six-month hearing on broadcast hicensing. ${ }^{35}$ The FCC's decision was made only after a comprehensive investigation in which notice of the proposed regulations was pubhished in the Federal Register and copies were sent to "every station licensee and network organization." 36 The Court held that "[t]he court below correctly held that its inquiry was limited to review of the evidence before the Commission."37

New Deal advocates touted the agencies' ability to conduct this kind of broad investigation as their greatest strength. ${ }^{38}$ Agencies were considered better suited to fact finding than the judiciary. Dean Landis, for example, writing in 1938, believed that the judiciary was crippled in its exainination of important policy issues because it was limited to the evidence presented by the parties, whereas agencies had an opportunity to hear from nuinerous points of view. ${ }^{39}$ According to Landis, the investigative advantage of an adinimistrative process would allow agencies to reach the "right" answer-i.e., a decision that was based on an impartial and fair review of all relevant facts, rather than a decision based only on the facts as presented by the parties:

One . . . significant distinction between the adıninistrative and the judicial processes is the power of "independent" investigation possessed by the former. The test of the judicial process, traditionally, is not the fair disposition of the controversy; it is the fair disposition of the controversy upon the record as made by the parties....

... For [the adıninistrative] process to be successful in a particular field, it is imperative that controversies be decided as "rightly" as possible, independently of the formal record the parties themselves produce. The ultimate test of the administrative is the policy that it formulates; not the fairness as between the parties of the disposition of a controversy on a record of their own making. ${ }^{40}$

In addition to having the capacity to reach the "right" decisions, agencies were also considered well-suited to inarginalizing financial dif-

\footnotetext{
34. 319 U.S. 190 (1943).

35. Id. at $195,227$.

36. Id. at 195.

37. Id. at 227.

38. Rabin, supra note 1 , at 1267.

39. LANDIS, supra note 1, at 36 .

40. Id. at 37-39.
} 
ferences between interested parties. As Landis noted, parties who lacked financial backing were often unable to pursue their rights vigorously in court:

To restrict governmental intervention, in the determination of claims, to the position of an umpire deciding the inerits upon the basis of the record as established by the parties, presuines the existence of an equality in the way of the respective power of the litigants to get at the facts. ... In some spheres the absence of equal economic power generally is so prevalent that the umpire theory of administermg law is almost certain to fail. ${ }^{41}$

Administrative agencies, playing a role more akin to investigator than judge, ${ }^{42}$ could overcome these economic inequalities by providing a public forum and by initiating independent investigations. ${ }^{43}$

Finally, New Deal theorists respected and proinoted the expertise of administrative agencies. ${ }^{44}$ Agencies were understood not to act-like judges-as inere umpires, but to take the lead in gathering relevant information. ${ }^{45}$ Because agency technocrats could be relied upon to make impartial decisions in the public good, the judiciary's role in the administrative decisionmaking process was viewed as minimal. ${ }^{46}$

The judicial development of the record rule can thus be traced to a recognition of both the comprehensive nature of administrative procedures and agency expertise in formulating public policy. Once they had accepted these premises, courts began to use their reviewing power to focus on the underlying procedure rather than the substance of the agency decision. ${ }^{47}$ Where an agency had coinplied with the required procedural safeguards, the courts would overturn a decision only when it was so arbitrary or baseless that it could not be sustained by the agency's own record. ${ }^{48}$

\section{B. Judicial Review Under the Administrative Procedure Act}

In 1946, Congress passed the Administrative Procedure Act (APA $)^{49}$ to create a standard body of law applicable to administrative agencies. ${ }^{50}$ Its passage was, at least in part, a response to concerns that Congress had not sufficiently safeguarded private interests against rap-

41. Id. at 36.

42. See Rabin, supra note 1 , at 1267.

43. LANDIS, supra note 1 , at $36,37$.

44. See Stephen G. Breyer \& Richard B. Stewart, Administrative law and Regulatory Policy 28 (1979); Rabin, supra note 1, at 1267.

45. LANDIS, supra note 1 , at 36 .

46. See Rabin, supra note 1, at 1266-72.

47. Id. at 1193 .

48. See, e.g., SEC v. Chenery Corp., 318 U.S. 80, 87-88 (1943) (overruling an SEC order that could not be sustained on the equity grounds upon which the agency based the order).

49. 5 U.S.C. $\$ \S 551-706$ (1988).

50. See SHAPIRO, supra note 4, at 39. 
idly increasing administrative powers. ${ }^{51}$ As a result, the APA imposed certain procedural requirements on all federal agencies, and established provisions for judicial review of agency actions to protect against biased or inadequate investigations and arbitrary decisions. ${ }^{52}$

Formally, the APA is considered a "back-up statute,"53 meaning that it applies only where Congress does not specify administrative procedures to be followed in a given statute. ${ }^{54}$ In practice, however, inost administrative procedural requirements are governed either by the APA or by statutory provisions that mirror the Act's requirements.

The APA divides agency decisionmaking procedures into two categories: formal and informal. ${ }^{55}$ Formal procedures are triggered where Congress demands that an agency decision be made "on the record after opportunity for an agency hearing." 56 In this situation, the agency inust conduct a formal learing in which it receives evidence and allows crossexamination. ${ }^{57}$

Courts reviewing these formal agency decisions must determine whetlier the decision is supported by substantial evidence based on the review of the record. ${ }^{58}$ In these reviews of formal decisions, the courts have continued to uphold the record rule. Indicative of this is the 1963 case, United States v. Carlo Bianchi \& Co. ${ }^{59}$ Citing botlı Tagg Bros. and National Broadcasting Co., the Supreme Court upheld the use of a strict record rule. In this case, the standards of judicial review were governed by the provisions of the Wunderlicli Act, ratler thian the APA. ${ }^{60}$ The Wunderhich Act provided that arbitrations of government contract disputes brought before the Board of Claims would be final. ${ }^{61}$ In the adversarial hearing that was held before the Board of Claims, a formal record was made and each side had an opportunity to present evidence and conduct cross-exainination. ${ }^{62}$ The Court concluded that, in formal cases such as Carlo Bianchi, "tliis Court has held that consideration is to be

51. See Wong Yang Sung v. McGrath, 339 U.S. 33, 36-40, modified, 339 U.S. 908 (1950).

52. Id. at 41-45; see also Walter Gellhorn, The Administrative Procedure Act: The Beginnings,

72 VA. L. Rev. 219 (1986).

53. ShapiRo, supra note 4 , at 39.

54. Id.

55. GELLHORN ET AL., supra note 7, at 228 (chart illustrating formal and informal decisionmaking of APA); William F. Pedersen, Jr., Formal Records and Informal Rulemaking, 85 YALE L.J. 38, 39-41 (1975).

56. 5 U.S.C $\S 553(\mathrm{c})$ (1988) (discussing the requirements for agencies conducting formal rulemaking); id. § 554(a) (formal adjudication). The terms "formal" and "informal" have been used by commentators on the APA. See supra note 55. While the APA itself does not use such terms, this Comment employs them for the sake of clarity.

57. See 5 U.S.C. $\S \S 556,557$ (1988).

58. See id. $\S 706(2)(\mathrm{E})$.

59. 373 U.S. 709 (1963).

60. Id. at 714.

61. Id.

62. Id. at 711 . 
confined to the admmistrative record and that no de novo proceeding may be held." 63

Unlike formal agency action, informal agency action, where Congress has not required agencies to comply with formal record and hearing requirements, is subject to few controls under the APA. ${ }^{64}$ The APA does impose some procedural requirements on agencies engaged in informal rulemaking - i.e., the agency must give notice of and receive comments on proposed rulemaking. ${ }^{65}$ However, all other types of informal agency decisions, loosely classified under the default heading "informal agency adjudication," receive little attention in the APA. ${ }^{66}$

Nevertheless, informal agency actions are subject to judicial review under the APA. ${ }^{67}$ A court may overturn an informal action, for example, that is "arbitrary, capricious, an abuse of discretion, or otherwise not in accordance with law" 68 or "without observance of procedure required by law."69 Thus, courts can review informal agency action under the APA despite the lack of comprehensive parameters governing such action.

However, applymg the record rule to review such informal agency actions presents difficulties. ${ }^{70}$ The APA provides no guidance as to what constitutes the record when an informal agency action is challenged in court. Nevertheless, in reviewing both formal and informal agency action, the court is instructed to "review the whole record or those parts of it cited by a party"71 - a mandate broad enough, as one coinmentator has argued, "to justify including virtually anything a party might want to present to a reviewing court."72 For informal agency actions, then, the administrative record is often a chimera that must be reconstructed in retrospect and whose content is often subject to heated debate. The offi-

63. Id. at 715. The Court concluded that the statutory intent to create a proceeding that would allow full evidentiary presentations and rebuttal "would be frustrated if either side were free to withhold evidence at the administrative level and then to introduce it in a judicial proceeding." Id. at 717. As in Tagg Bros., the Court held that the appropriate procedure for challenging a defective, inadequate, or prejudicial record was to stay the court proceedings and remand to the agency for further action. Id. at 717-18.

64. See Pedersen, supra note 55, at 41 (stating that "[t]he statutory requirements for informal rule-making . . . are limited").

65. 5 U.S.C. $\S 553(b)$, (c) (1988).

66. See BREYER \& STEWART, supra note 44 , at 524-25.

67. See 5 U.S.C. $\$ \S 702,704,706$ (1988). In fact, the majority of challenges to agency decisions contest informal, rather than formal, agency action. Harold H. Bruf, Coordinating Judicial Review in Administrative Law, 39 UCLA L. REv. 1193, 1196 (1992).

68. 5 U.S.C. $\$ 706(2)(A)(1988)$.

69. Id. $\S 706(2)(\mathrm{D})$.

70. See Pedersen, supra note 55, at 39 (noting that even as late as the 1960s, significant regulatory schemes were based on trial-type hearings and arguing that if informal rulemaking were based on a clear record, as occurs with formal rulemaking and formal adjudication, "the efficiency of both [informal] rulemaking and judicial review would be increased").

71. 5 U.S.C. $\$ 706$ (1988).

72. Stark \& Wald, supra note 10 , at 340 . 
cial record may contain only a few items or extend to hundreds of volumes. Thus, the courts have struggled to establish common law rules of evidence for reviewing informal agency actions.

\section{Supreme Court Review of Informal Agency Action- the Modern Era}

The problems associated with review of informal agency decisions have concerned commentators and judges since the enactinent of the APA. ${ }^{73}$ During the 1950s, court opinions were far from uniform, applying a variety of different standards in reviewing informal adjudicatory actions. ${ }^{74}$ In 1965, Professor Jaffe criticized an Illinois statute as "ineptly drafted" because it "limits the record to the evidence taken by the agency" despite the fact that " $m$ a great many [administrative] mandamus situations the procedure is informal and there is no record."75 In the 1970s, courts began to impose additional procedures-such as hearings or opportunities for cross-exammation-on agencies undertaking imformal action to ensure that their decisions were made fairly and with adequate public input. ${ }^{76}$

However, in the last twenty years the Supreme Court has tended to sweep aside such concerns about the adequacy and fairness of adninistrative hearings for niformal agency decisions. Instead, the Court has focused on creating an efficient judicial review process, whereby courts review agency decisions based on the informal administrative record coinpiled by the agency. In particular, the Court has restricted the judiciary's power to demand that agencies engage in additional fact-finding procedures.

The Supreme Court first grappled with the standards for judicial review of informal agency action in 1971. In Citizens to Preserve Overton Park, Inc. v. Volpe, ${ }^{77}$ the Court held that judicial review of the Secretary of Transportation's decision to build a highway through a public park must be based on more than the affidavits that the parties prepared for hitigation. ${ }^{78}$ The Court remanded the case to the district court for review

73. See generally BREYER \& STEWART, supra note 44, at 522-29.

74. See Note, Judicial Review of Administrative Adjudicatory Action Taken Without a Hearing, 70 HARV. L. REv. 698 (1957) (outlining the available standards of review and arguing that whether the administrative action is based on findings of fact or conclusions of law largely determines which standard should be applied).

75. JAFFE, supra note 1 , at 161 . Jaffe also notes that "[w]hether to take new evidence will depend on the fairness and completeness of the administrative hearing or investigation" and that "[i]f the hearing has been partial or perfunctory, the court may take evidence or if such a procedure is possible return the case to the agency for further action if the issues are too technical." Id. at 187.

76. See Richard B. Stewart, Vermont Yankee and the Evolution of Administrative Procedure, 91 HARv. L. REv. 1805, 1811-14 (1978) (discussing the development of judicially imposed requirements on informal rulemaking through the mid-1970s).

77. 401 U.S. 402 (1971).

78. Id. at 409 . 
"based on the full admmistrative record that was before the Secretary at the time he made his decision."79

The Overton Park Court, however, did not limit the district court's review of informal agency action to the administrative record. The Court noted that the district court must make a "searching and careful" factual inquiry in order to determine whether the administrative decision was "based on a consideration of the relevant factors and whether there has been a clear error of judgment." ${ }^{80}$ The Supreme Court noted that if, after remand, the admimstrative record failed to illuminate the rationality of the agency decision, the district court could hear explanatory testimony from agency officials:

[S]ince the bare record may not disclose the factors that were considered or the Secretary's construction of the evidence it may be necessary for the District Court to require some explanation in order to determine if the Secretary acted within the scope of his authority and if the Secretary's action was justifiable under the applicable standard.

The court may require the administrative officials who participated in the decision to give testimony explaining their action. ${ }^{81}$

By allowing the admission of testimony by administrative officials, the Overton Park Court created an exception to the record rule in certain cases where the record is insufficient. ${ }^{82}$

Overton Park is also known for establishing the "hard look" doc-

79. Id. at 420. On remand, this administrative record did not materialize without a great deal of effort, requiring 25 days of trial and the introduction of 240 exhibits. See Citizens to Preserve Overton Park, Inc. v. Volpe, 335 F. Supp. 873, 878 (W.D. Tenn. 1972), rev'd, 494 F.2d 1212 (6th Cir. 1974), cert. denied, 421 U.S. 991 (1975). Thus, the informal administrative decision process was transformed into a highly formal judicial proceeding.

80. Overton Park, 401 U.S. at 416.

81. Id. at 420.

82. While citing United States v. Morgan, 313 U.S. 409, 422 (1941), for the proposition that courts should not probe the mental processes of the agency decision-makers, the Overton Park Court held that where there are no formal findings, requiring an agency official to testify "may be ... the only way there can be effective judicial review." Overton Park, 401 U.S. at 420.

Although the Overton Park Court did not apply a strict form of the record rule, it rejected the application of a de novo review of most informal administrative actions. The Court held that de novo review is appropriate only where the "action is adjudicatory in nature and the agency factfinding procedures are inadequate" and when "issues that were not before the agency are raised in a proceeding to enforce nonadjudicatory agency action." Id. at 415 .

Several commentators have noted that, according to the legislative history, the APA did not contemplate so narrow a restriction of de novo review. Rather, as the Congressional reports state, the "unwarranted by the facts" standard of S U.S.C. $\$ \$ 556-557$ (1988) "require[s] the judicial determination of facts in connection with rule making or any other conceivable form of agency action to the extent that the facts were relevant to any pertinent issues of law presented." S. REP. No. 752, 79th Cong., 1st Sess. 28 (1945), quoted in Nathaniel L. Nathanson, Probing the Mind of the Administrator: Hearing Variations and Standards of Judicial Review Under the Administrative Procedure Act and Other Federal Statutes, 75 Colum. L. Rev. 721, 763-64 n.187 (1975) (also citing H.R. REP. No. 1980, 79th Cong., 2nd Sess. 45 (1946) for the same proposition); see also Stephen F. 
trine, which deinands that courts make a "thorough, probing, in-depth review" of agency action. ${ }^{83}$ According to this doctrine, while the court inay not judge the substantive merits of the agency's decision or "interject itself within the area of discretion of the executive," ${ }^{84}$ the court must ensure that the agency has taken a "hard look" at data that is relevant to its final decision. ${ }^{85}$ This elevated standard of review set forth in Overton Park reflects a judicial willingness to place more stringent demands on agencies and a greater reluctance to defer to claims of agency expertise and independence.

Thus, while Overton Park requires a court to look at the record to determine whether an agency action is reasonable, it cannot be read as establishing a strict record rule im all actions involving infornnal agency action. By allowing for the adimission of additional testimony in some cases, the Court opened the door to an exception to the record rule where "the bare record [does] not disclose the factors that [the agency] considered or the [agency's] construction of the evidence."

The Court more clearly endorsed on-the-record review of infornal agency proceedings two years later in Camp v. Pitts. ${ }^{87}$ In Camp, the Comptroller of Currency denied the plaintiffs authorization to establish a new bank in South Carolina, and the district court denied plaintiffs' motion for summary judgment on review of the Comptroller's action. ${ }^{88}$ The court of appeals found the administrative record insufficient for adequate judicial review and remanded the case to the district court for a de novo trial. 89

The Suprenie Court found the court of appeals' instructions to the district court unwarranted. Rather, in applying the APA's "arbitrary and capricious" standard to informal agency decisions, the Court lield that "the focal point for judicial review should be the adninistrative record already in existence, not soine new record made initially in the reviewing court." "90 The Court held that the remedy for inadequate explication of agency action is not an evidentiary hearing in court but a remand of the inatter to the agency. ${ }^{91}$ Similarly, where the agency artic-

Williams, "Hybrid Rulemaking" Under the Administrative Procedure Act: A Legal and Empirical Analysis, 42 U. CHI. L. REV. 401, 419-20 n.76 (1975).

83. Overton Park, 401 U.S. at 415.

84. Kleppe v. Sierra Club, 427 U.S. 390, 410 n.21 (1976) (quoting Natural Resources Defense Council v. Morton, 458 F.2d 827, 838 (D.C. Cir. 1972)).

85. For a discussion of the application of the hard look doctrine in environmental cases, see generally Kathleen W. Marcel, The Role of the Courts in a Legislative and Administrative Legal System-The Use of Hard Look Review in Federal Environmental Litigation, 62 OR. L. REV. 403 (1983).

86. Overton Park, 401 U.S. at 420.

87. 411 U.S. 138 (1973).

88. Id. at $138-39$.

89. Id. at $139-40$.

90. Id. at 142.

91. Id. at $142-43$ " If . . there was such failure to explain administrative action as to frustrate 
ulates reasons for its actions, but those reasons are not sustainable on the record, the agency's action must be vacated and then remanded to the agency. ${ }^{92}$

The Court upheld this trend in Florida Power \& Light Co. v. Lorion. ${ }^{93}$ At issue was the D.C. Circuit's initial jurisdiction over appeals from the Nuclear Regulatory Commission. ${ }^{94}$ The D.C. Circuit had found that it had no jurisdiction to review a complaint against a local nuclear power plant. ${ }^{95}$ The court reasoned that since the Cominission had not held a hearing, jurisdiction over the case should be placed in the district court. ${ }^{96}$

The Supreme Court reversed, holding that Congress did not intend the availability of appellate court review to rest upon the existence of a hearing. ${ }^{97}$ The Court found that "[p]erhaps the only plausible justification for linking initial review in the court of appeals to the occurrence of a hearing before the agency would be that, absent a hearing, the reviewing court would lack an adequate agency-compiled factual basis to evaluate the agency action .....98 The Court rejected this justification, however, reiterating Camp's holding that " the focal point for judicial review should be the administrative record already in existence." "99 The Court continued:

If the record before the agency does not support the agency action, if the agency has not considered all relevant factors, or if the reviewing court simply cannot evaluate the challenged agency action on the basis of the record before it, the proper course, except in rare circumstances, is to remand to the agency for additional investigation or explanation. The reviewing court is not generally empowered to conduct a de novo inquiry into the matter being reviewed and to reach its own conclusions based on such an inquiry.... Moreover, a fornal hearing before the agency is in no way necessary to the compilation of an agency record. . . . The APA specifically contemplates judicial review on the basis of the

effective judicial review, the remedy was not to hold a de novo hearing but . . . to obtain from the agency ... such additional explanation of the reasons for the agency decision as may prove necessary.").

92. Id. at 143 .

93. 470 U.S. 729 (1985).

94. Id. at 731 .

95. Id. at $733-34$.

96. Id. at 734, n.5.

97. Id. at 741-45.

98. Id. at 743. This argument had been made a decade earlier by Judge Harold Leventhal of the D.C. Circuit, who saw the district courts playing a larger role in resolving factual issues. See Harold Leventhal, Environmental Decisionmaking and the Role of the Courts, 122 U. PA. L. REV. 509,544 (1974) (arguing that "[p]lacing the initial forum in the district court allows a thoroughgoing inquiry into the bases of decision ... provid[ing] a record without which appellate review, at least within its confines, would be largely ineffective.").

99. Lorion, 470 U.S. at 743 (quoting Camp v. Pitts, 411 U.S. 138, 142 (1973)). 
agency record compiled in the course of informal agency action in which a hearing has not occurred.

The factfinding capacity of the district court is thus typically unnecessary to judicial review of agency decisionmaking. ${ }^{100}$

Thus, Lorion appears to establish a general rule of review on the record, even for informal agency decisions. When confronted with agency decisions that are poorly articulated, unreasonable, or not supportable on the record, courts should remand to the agency for further justification.

Overton Park, Camp, and Lorion evince little judicial concern about agencies' abilities to develop a record adequate for judicial review. The Court addressed this issue more directly in Vermont Yankee Nuclear Power Corp. v. Natural Resources Defense Council, Inc. ${ }^{101}$ In Vermont Yankee, the Supreme Court held that courts, absent substantial justification, could not force agencies that meet the minimum APA procedural requirements to develop procedures for more comprehensive fact-finding. ${ }^{102}$ While acknowledging that the courts could remand to the agency where the record was madequate, the Court reiterated the "very basic tenet of administrative law that agencies should be free to fashion their own rules of procedure."103

Many commentators have viewed the Vermont Yankee opinion as crippling the judiciary's ability to deal witl the growing body of administrative law. Professor Stewart, for example, commented that "[i]n freezing most administrative procedures in the obsolescent model established by the APA in 1946, [the decision] ignores the ... need for developing new procedures that will generate an adequate evidentiary record enabling courts to review the substantive validity of agency decisions."104 In effect, the opmion makes remand simply an opportunity for

100. Id. at 744 .

101. 435 U.S. 519 (1978).

102. Id. at $544-45$ (agreeing with the policy articulated in SEC v. Chenery Corp., 332 U.S. 194, 196 (1947)). Vermont Yankee involved a challenge to informal rulemaking, which must meet specific APA requirements. Thus, the case may be less applicable to other informal administrative decisionmaking processes.

103. Id. at 544.

104. Stewart, supra note 76, at 1805. For further criticisms of this decision, see Kenneth C. Davis, Administrative Common Law and the Vermont Yankee Opinion, 1980 UTAH L. ReV. 3 (criticizing the decision as inconsistent with the principles of common law, the APA, and the APA's legislative history); Nathaniel L. Nathanson, The Vermont Yankee Nuclear Power Opinion: A Masterpiece of Statutory Misinterpretation, 16 SAN DIEGo L. REV. 183 (1979) (arguing that the Court based its decision on the wrong provisions of the APA); William H. Rodgers, Jr., A Hard Look at Vermont Yankee: Environmental Law Under Close Scrutiny, 67 GEo. L.J. 699 (1979) (concluding that Vermont Yankee is inconsistent with prior doctrine concerning judicial review of administrative action). The "hybrid" procedures (i.e., those between the informal and formal standards) which had been developed by the D.C. Circuit and other circuit courts and which the Supreme Court rejected in Vermont Yankee are further explored in Williams, supra note 82. Williams asserts that "statutory facts" (i.e., "facts needed to ascertain whether an agency's regulation is within its statutory power") should be subject to judicial resolution in the same manner as constitutional facts. Id. at 422-23. 
the agency to develop a record that will support its decisions, without the interference of court-imposed requirements (such as hearings and opportunities for cross-examination) in agency proceedings.

These modern Supreme Court cases reflect a clear, if not very welldeveloped, preference for limiting judicial review to the agency record, regardless of the formahity of the administrative proceedings. The rule seems to be premised on widespread, but often unarticulated, assumptions: that courts should respect agency expertise and independence; that even the limited records of informal proceedings are sufficient for adequate judicial review; and that parties have obligations to make their objections before the agency prior to making them in court.

While the record rule may tend to favor agencies in informal actions, it also places constraints on the government. Early on, the Court held that "the grounds upon which the administrative agency acted [must] be clearly disclosed and adequately sustained."105 An agency must "give clear indication that it has exercised the discretion with which Congress has empowered it."106 By setting out its own rationale for its action, the agency provides a framework for the reviewing court, which can affirm or reject the logic of the agency rationale. In this way, the court avoids competing with the agency and reaching "its own conclusions" after an independent inquiry, ${ }^{107}$ or "substitut[ing] its judgment for that of the agency." 108 Professor Jaffe summarized the purpose of judicial review as "provid[ing] minimum assurance that there is record evidence which provides a rational or logical basis for the [agency] finding." 109

Despite the limitations that the record rule imposes on judicial review of informal agency action, Supreme Court precedent allows the courts to go beyond the record in some instances and thus does not mandate an absolute bar on extra-record review. Overton Park requires that a court's review be "based on," not limited to, the record before the agency. ${ }^{110}$ As noted above, Overton Park allows the court to go beyond the bare record to obtain an explanation of the decision-maker's action. "11 Camp holds only that the record should be the "focal point for judicial review,"112 not that new evidence should not be admitted. A

105. SEC v. Chenery Corp., 318 U.S. 80,94 (1943).

106. Id. at 94-95 (quoting Phelps Dodge Corp. v. NLRB, 313 U.S. 177, 197 (1941)).

107. See Florida Power \& Light Co. v. Lorion, 470 U.S. 729, 744 (1985).

108. Citizens to Preserve Overton Park v. Volpe, 401 U.S. 403, 416 (1971).

109. JAFFE, supra note 1 , at 601 . Moreover, courts must consider the evidence evenhandedly. Placing some limits on judicial deference to agency justifications, the Supreme Court in Universal Camera Corp. v. NLRB, 340 U.S. 474 (1951), for the first time asserted that the "substantial evidence" test for on-the-record formal review must be applied on the basis of the entire record before the agency, not simply on the materials that support the agency's point of view. $I d$. at 488 .

110. Overton Park, 401 U.S. at 420.

111. Id.; see supra text accompanying notes 77-86.

112. Camp v. Pitts, 411 U.S. 138, 142 (1973). 
focal point is, after all, a "center of interest," 113 not a boundary line. Finally, Lorion claims to articulate only a general rule, which nay be broken in "rare circuinstances." 114

Thus, Supreme Court precedent seems to leave room for exceptions to the record rule, although the scope and content of these exceptions are unclear. As a result, the record rule has been applied unevenly to the growing number of cases that challenge informal agency action. ${ }^{115}$ In determining whether a rigid application of the record rule is appropriate, courts inust look both at the policies supporting the rule and to the goals of the underlying statute. One statute that has been repeatedly simgled out in creating exceptions to the record rule is the National Environmental Policy Act.

\section{II \\ THE NEPA EXCEPTION TO THE RECORD RULE}

\section{A. An Overview of NEPA}

Congress enacted the National Environmental Policy Act of 1969 (NEPA) with high-minded political goals. ${ }^{116}$ According to the text of the statute, NEPA's purposes were to

declare a national policy which will encourage productive and enjoyable harmony between inan and his environinent; to proinote efforts which will prevent or eliminate damage to the environinent and biosphere and stimulate the health and welfare of man; [and] to enrich the understanding of the ecological systems and natural resources important to the Nation . . . .117

Despite these substantive goals, however, the Supreme Court has interpreted NEPA's mandate to agencies as "essentially procedural." 118 NEPA requires that all federal agencies prepare a "detailed statement" of a proposed prograin's environmental impacts before approving "major Federal actions significantly affecting the quality of the human environinent."119 These "environmental impact statements" (or EISs) must also

113. Webster's THIRD NEW INTERNATIONAL Dictionary 881 (1986).

114. Florida Power \& Light Co. v. Lorion, 470 U.S. 729, 744 (1985).

115. Steven Stark and Sarah Wald insist that the rule laid down in Overton Park is unworkable if rigidly applied and that as a result, "in many cases where a circuit court announced its allegiance to [the record] rule, the court then broke the rule by allowing evidence from outside the administrative record as defined by the agency." Stark \& Wald, supra note 10, at 343. For a review of the types of cases in which the courts allowed evidence, see $i d$. at 343-54.

116. See 42 U.S.C. $\S 4321$ (1988). For a discussion of the passage and early implementation of NEPA, see generally FREDERICK R. ANDERSON, NEPA IN THE COURTS (1973). For a more recent survey of moderu NEPA law, see generally VALERIE M. FogLEMAN, GUIDE TO THE NATIONAL ENVIRONMENTAL Policy ACT (1990).

117. 42 U.S.C. $\S 4321$ (1988).

118. Vermont Yankee Nuclear Power Corp. v. Natural Resources Defense Council, Inc., 435 U.S. 519,558 (1978).

119. 42 U.S.C. $\S 4332(2)(C)(1988)$. 
address unavoidable "adverse environmental effects" of the action, ${ }^{120}$ "alternatives to the proposed action," term effects of the action, 122 and "any irreversible and irretrievable commitments of resources" that could occur if the action were implemented. ${ }^{123}$ These requirements have been supplemented by regulations issued by the Council on Environmental Quality (CEQ). ${ }^{124}$

If the agency is uncertain whether the impacts of a project are potentially significant, the agency must prepare an initial environmental assessment (EA) that considers both quasi-political factors (including the unique characteristics of the area and the controversy surrounding the decision) and scientific questions (such as the uncertainty of the environmental effects and the cumulative impact of the project). ${ }^{125}$ After completing the EA, if the agency determines either that impacts of the project are not significant or that the action to be taken is not "major," the agency may issue a "finding of no significant impact" (FONSI) and need not prepare an EIS. ${ }^{126}$

If an agency decides to prepare an EIS, the CEQ regulations direct that impacts be discussed "in proportion to their significance."127 In addition, the EIS must respond to comments from any outside party either by modifying its alternatives, data, or analysis, or explaining why modification is not necessary. ${ }^{128}$ Finally, the agency must prepare a record of decision that identifies the proposed action and identifies all alternatives and factors considered by the agency. ${ }^{129}$

NEPA is designed to perform an educational function. NEPA's basic preinise is that a better knowledge base will cause agencies to make less environmentally damaging decisions. ${ }^{130}$ NEPA, and CEQ implementing regulations, impose a nuınber of duties on agencies to ensure that they educate themselves about the possible environmental impacts of

120. Id. $\S 4332(2)(\mathrm{C})(\mathrm{ii})$.

121. Id. $\S 4332(2)(\mathrm{C})(\mathrm{iii})$.

122. Id. $\S 4332(2)(\mathrm{C})(\mathrm{iv})$.

123. Id. $\S 4332(2)(\mathrm{C})(\mathrm{v})$.

124. CEQ has issued extensive regulations governing the preparation of EAs and EISs. See 40 C.F.R. $\$ \S 1500-1508$ (1992). The Supreme Court has held that "CEQ regulations are entitled to substantial deference." Robertson v. Methow Valley Citizens Council, 490 U.S. 332, 355 (1989) (citing Andrus v. Sierra Club, 442 U.S. 347, 358 (1979)).

125. 40 C.F.R. $\S \S 1501.3,1508.27$ (1992).

126. Id. $\S 1501.4(\mathrm{e})$.

127. Id. $\S 1502.2(\mathrm{~b})$. The E1S must contain a discussion of direct and reasonably foreseeable indirect effects and their significance. Id. $\S \S 1502.16,1508.8$. These effects may be eeological, aesthetic, historic, cultural, economic, social or health-related. Id. $\S 1508.8$.

128. Id. $\S 1503.4(\mathrm{a})$.

129. Id. $\S \S 1502.2,1502.19$.

130. See id. $\S 1500.1$ (c) ("NEPA's purpose is not to generate paperwork-even excellent paperwork-but to foster excellent action. The NEPA process is intended to help public officials make decisions that are based on an understanding of environmental consequenees, and take actions that protect, restore, and enhance the environment."). 
their actions. ${ }^{131}$ In addition, in creating EAs and EISs, an agency educates the public about the possible environmental consequences of proposed agency action. ${ }^{132}$ The Supreme Court has acknowledged the importance of these dual educational goals:

[NEPA] ensures that the agency, in reaching its decision, will have available, and will carefully consider, detailed information concerning significant environmental impacts; it also guarantees that the relevant information will be made available to the larger audience that may also play a role in both the decisionmaking process and the implementation of that decision. ${ }^{133}$

Public education is a crucial element of NEPA. If EAs and EISs accurately portray environmental risks, these documents can form the basis for more participatory and democratic decisionmaking. ${ }^{134}$ Indeed, courts have long acknowledged the important role of NEPA environmental reviews in focusing "Government and public attention on the environmental effects of proposed agency action." 135 Without a responsive and educated public, both general and congressional, there is hittle hope that NEPA will play a significant role in environinental protection.

Legal challenges to agency decisions under NEPA typically involve claims that an agency should have prepared an EIS or that the EIS was prepared inadequately. ${ }^{136}$ These claims in turn often lead to quasi-factual disagreements over whether (1) the action will significantly affect the environment, ${ }^{137}(2)$ the agency has properly analyzed the relevant envi-

131. NEPA requires that agencies identify possible environmental effects and values, id. $\S 1501.2$ (b); study, develop, and describe alternatives, $i d$. $\S 1501.2(\mathrm{c})$; consult with other interested agencies, individuals, and organizations, $i d$. $\$ 1501.2(\mathrm{~d})(2)$; develop an interdisciplinary approach to their analysis, 42 U.S.C. $\S 4332(\mathrm{~A})(1988)$; and, finally, prepare and circulate the appropriate NEPA document, 40 C.F.R. $\S 1502.19$ (1992).

132. See 40 C.F.R. $\$ 1500.2$ (establishing the policy that agencies, "to the fullest extent possible[, ... [e]ncourage and facilitate public involvement in decisions which affect the quality of the human environment").

133. Robertson v. Methow Valley Citizens Council, 490 U.S. 332, 349 (1989).

134. See Walter A. Rosenbaum, Environmental Politics and Policy 268 (1985) (noting that "EISs became an early warning system for environmental groups, alerting them to the implications of numerous agency policies whose importance might otherwise have been ignored. Environmentalists thus had opportunity to organize a political strategy for influencing land management decisions.").

135. Marsh v. Oregon Natural Resources Council, 490 U.S. 360, 371 (1989); see also Natural Resources Defense Council, Inc. v. Hodel, 865 F.2d 288, 296 (D.C. Cir. 1988) (stating that NEPA's requirement that agencies consider alternatives "is not merely to force the agency to reconsider its proposed action, but, more broadly, to inform Congress, other agencies, and the general public about the environmental consequences of a certain action in order to spur all interested parties to rethink the wisdom of the action").

136. See Council on Envtl. Quality, Twentieth AnNual Report app. B at 392 (1990) [hereinafter CEQ 20TH ANNUAL REPORT] (noting that from 1974 to 1988, failure to prepare an EIS was generally the most common complaint, followed by claims that an EIS was inadequately prepared).

137. See, e.g., Save the Yaak Comm. v. Block, 840 F.2d 714, 718 (9th Cir. 1988) (plaintiffs alleged that an EA overlooked significant effects on wildlife, plant life, and recreation); Natural 
ronmental impacts, ${ }^{138}$ and (3) new information is significant enough to warrant a supplemental EIS. ${ }^{139}$ These issues contain a common inquiry: whether the environmental impact of a particular action requires further NEPA analysis. The answer to this inquiry almost always involves complicated scientific determinations, conflicting evidence, and incomplete data.

Courts, however, are not authorized to vacate an agency decision under NEPA because it is unwise or will have a negative effect on the environment. ${ }^{140}$ Instead, a reviewing court's scrutiny is limited to determining whether an agency has followed NEPA procedure, i.e., whether an agency has properly prepared, or reasonably failed to prepare, an EIS. Failure to comply with CEQ or comparable agency procedural requirements inay also mvatidate an agency's NEPA review. ${ }^{141}$

\section{B. County of Suffolk and the Development of the NEPA Exception}

In reviewing informal agency action under NEPA, lower courts have not found clear Supreme Court precedent regarding the application of the record rule. In early cases under NEPA, courts struggled to determine the appropriate standard of review and the means of establishing the record, and often assumed without discussion that it was appropriate for courts to take additional evidence.

Resources Defense Council, Inc. v. Duvall, 777 F. Supp. 1533 (E.D. Cal. 1991) (plaintiffs challenged the agency's decision to prepare only an EA and FONSI rather than an EIS on water-pricing regulation).

138. See, e.g., Marble Mountain Audubon Soc'y v. Rice, 914 F.2d 179, 182 (9th Cir. 1990) (plaintiffs alleged that the EIS failed to discuss the importance of preserving a biological corridor for wildlife); People ex rel. Van de Kamp v. Marsh, 687 F. Supp. 495, 501 (N.D. Cal. 1988) (holding that the EA "did not adequately address the wetlands, wildlife, and endangered species impacts, water quality impacts, noise impacts, cumulative impacts, or the adequacy of the mitigation proposal").

139. See, e.g., Marsh v. Oregon Natural Resources Council, 490 U.S. 360 (1989) (challenge of an agency's decision not to prepare a supplementary EIS). If, after preparing the final EIS, the agency makes substantial changes to the proposed action or discovers new circumstances or information relevant to the environmental impacts of the project, the agency must prepare a supplemental EIS to address the changed circumstances. 40 C.F.R. $\S 1502.9$ (c) (1992). An EIS may be supplemented as long as a final decision is delayed until the new information has been reviewed. Natural Resources Defense Council, Inc. v. Callaway, 524 F.2d 79, $91-92$ (2d Cir. 1975). This Comment is primarily concerned with challenges alleging the need for, or the inadequacy of, an initial EA or EIS, rather than challenges alleging that a supplemental EIS should be prepared.

140. See Strycker's Bay Neighborhood Council, Inc. v. Karlen, 444 U.S. 223, 227-28 (1980) ("[O]nce an agency has made a decision subject to NEPA's procedural requirements, the only role for a court is to insure that the agency has considered the environmental consequences; it cannot interject itself within the area of discretion of the executive as to the choice of the action to bc taken." ") (citing Kleppe v. Sierra Club, 427 U.S. 390, 410 n.21 (1976)). NEPA has not always been interpreted as having no substantive content and the environmental community has found the Supreme Court's limited interpretation of NEPA disappointing. See Nicholas C. Yost, NEPA's Promise-Partially Fulfilled, 20 ENVTL. L. 533 (1990) (blaming the Supreme Court for failing to endorse NEPA's substantive mandate).

141. See Oregon Natural Resources Council, 490 U.S. at $371-73$ (1989) (discussing agencies' duties under both CEQ regulations and agencies' own implementing regulations). 
In 1973, several circuit courts expressed apparent approval for extra-record evidence in NEPA cases. ${ }^{142}$ In Save Our Ten Acres $\nu$. Kreger, for example, the Fifth Circuit explained that, where agency developinent of evidence was inadequate, the court could look to "supplemental affidavits, depositions and other proof concerning the environinental impact of the project."143 This willingness to review stemmed from the court's behef that only a demanding standard of judicial review could uphold NEPA's preservatiomist goals:

NEPA was intended not only to insure that the appropriate responsible official considered the environmental effects of the project, but also to provide Congress (and others receiving such recommendation or proposal) with a sound basis for evaluating the environmental aspects of the particular project or program. The spirit of the Act would die aborning if a facile, ex parte decision that the project was minor or did not significantly affect the environment were too well shielded froin impartial review. ${ }^{144}$

Thus, as of 1973, a trend to create a NEPA exception to the record rule began to emerge.

This trend found its greatest support a few years later when, in 1977, the Second Circuit decided County of Suffolk v. Secretary of Interior. ${ }^{145}$ Surfacing as the cornerstone of the NEPA exception, County of Suffolk remains today the leading authority for the proposition that a reviewing court may look outside of the administrative record in NEPA cases. ${ }^{146}$

In County of Suffolk, plaintiffs challenged an EIS prepared by the Secretary of Interior concerning the leasing of government land for oil and gas exploration, production, and developinent. ${ }^{147}$ In its lengthy examination of the adequacy of the EIS, the court expressed approval for the district court's decision to expand its review beyond the administrative record. ${ }^{148}$ In commg to this determination, the Second Circuit focused on the fact that NEPA places the burden of conducting a thorough environmental review on the federal agencies. ${ }^{149}$ Thus, plain-

142. See Maryland-National Capital Park \& Planning Comm'n v. United States Postal Serv., 487 F.2d 1029, 1041 n.13 (D.C. Cir. 1973) (stating that "[i]n the absence of detailed findings from the agency, a trial-type exploration" may be needed to help focus the NEPA issues before the court on remand); Silva v. Lynn, 482 F.2d 1282, 1284 (1st Cir. 1973) (noting that agencies must produce a full administrative record in order to diminish "the need for taking additional evidence in court"); Save Our Ten Acres v. Kreger, 472 F.2d 463, 467 (5th Cir. 1973) (allowing for expansive review of available evidence, while emphasizing that courts should not make decisions on the ultimate merits of the project).

143. Save Our Ten Acres, 472 F.2d at 467.

144. Id. at 466.

145. 562 F.2d 1368 (2d Cir. 1977), cert. denied, 434 U.S. 1064 (1978).

146. See MANDELKER, supra note 15, § 4.09[1][b].

147. County of Suffolk, 562 F.2d at 1372-73.

148. Id. at 1383-84.

149. Id. at 1384. 
tiffs should not be restricted to the evidentiary record they placed before the agencies when challenging their actions in court: "[I]n NEPA cases ... a primary function of the court is to insure that the information available to the decision-maker includes an adequate discussion of environmental effects and alternatives, which can sometimes be determined only by looking outside the administrative record to see what the agency may have ignored." 150

The court then set out guidelines for the types of extra-record evidence that a reviewing court may consider:

Generally ... allegations that an EIS has neglected to mention a serious environmental consequence, failed adequately to discuss some reasonable alternative, or otherwise swept "stubborn problems or serious criticism ... under the rug," raise issues sufficiently important to permit the introduction of new evidence in the district court, includimg expert testimony with respect to technical matters, both in challenges to the sufficiency of an environmental impact statement and in suits attacking an agency determination that no such statement is necessary. ${ }^{151}$

While the County of Suffolk court granted broad authority to review information outside of the administrative record, it held that this additional evidence should be "probative only insofar as it tended to show either that the agency's research or analysis was clearly inadequate or that the agency iniproperly failed to set forth opposing views widely shared in the relevant scientific community."152

Finally, the County of Suffolk court rejected the agency's argument that, by permitting the plaintiffs to present extra-record evidence, it was encouraging sandbagging that would disrupt the agency's function:

Nor can we accept appellants' contention that plaintiffs' failure to present the evidence to the Department in the first instance for incorporation into the EIS barred its consideration by the district court. To so hold would in effect shift the burden of insuring the adequacy of the EIS to environmental challengers, even though the primary and nondelegable responsibility for providing such an analysis lies with the agency. ${ }^{153}$

County of Suffolk laid the groundwork for wide acceptance of plaintiffs' use of extra-record evidence in challenging agencies' compliance with NEPA. The use of evidentiary trials and hearings, expert witnesses, and expert affidavits and other evidentiary documents challenging agencies' environmental reviews has become commonplace in NEPA cases,

150. Id. (citations omitted).

151. Id. at 1384-85 (quoting Silva v. Lynn, 482 F.2d 1282, 1285 (1st Cir. 1973) (citation and footnote omitted) (second alteration in original)).

152. Id. at 1385.

153. Id. (footnote omitted). 
especially in those circuits that are most familiar with NEPA. ${ }^{154}$

The rationale behind courts' acceptance of extra-record evidence, however, is rarely fully articulated. A few circuits have followed the reasonimg of Suffolk exphicitly. ${ }^{155}$ Many circuits, however, allow evidence inconsistently or under broader theories that go beyond the confines of NEPA.

Some circuits seem to accept extra-record evidence im NEPA cases almost as a matter of course. The Fifth Circuit, for example, has routinely referred to the district courts' acceptance of extra-record evidence in NEPA cases without special comment. ${ }^{156}$ The Eleventh Circuit also appears to presume that extra-record evidence is acceptable in NEPA

154. An informal Westlaw search of district and appellate cases referring to NEPA over the last ten years-from April 1983 through March 1993-showed 265 cases in the Ninth Circuit, as opposed to 39 in the Seventh Circuit. The five circuits with the highest number of cases-Ninth (265), D.C. (132), Second (69), Fifth (52), and Tenth (46)-all allow relatively expansive use of extra-record evidence in NEPA cases. See supra notes 142-53 and accompanying text; infra notes 155-64 and accompanying text.

155. For example, in Izaak Walton League of Am. v. Marsh, 655 F.2d 346 (D.C. Cir. 1981), the court cited County of Suffolk as support for the proposition that a strict record rule cannot be found in Overton Park or the APA:

By referring to the APA and the Supreme Court's decision in Overton Park, we do not mean to imply that judicial review of [a final EIS] should be limited to the contents of the original administrative record, or that the District Court erred when it decided to permit introduction of new evidence. Suits challenging environmental impact statements seek to ensure compliance with a statute other than the APA. The reviewing court must ensure that the agency decision adequately discusses environmental effects and alternatives. Allegations that an impact statement fails to consider serious environmental consequences or realistic altematives raise issues sufficiently important to warrant introduction of new evidence in the District Court.

Id. at 369 n.56 (citation omitted); see also Coalition on Sensible Transp., Inc. v. Dole, 826 F.2d 60, 72 (D.C. Cir. 1987) (citing Izaak Walton League in noting that plaintiffs "were entitled to introduce evidence tending to show significant impacts or realistic alternatives that the responsible officials ignored"); Atchison, T. \& S.F. Ry. v. Alexander, 480 F. Supp. 980, 986, 989 (D.D.C. 1979) (indieating that plaintiffs introduced "six expert witnesses, excerpts of depositions and hundreds of documentary exhibits," and upholding the principle that "under NEPA, an evidentiary hearing was appropriate to assess the sufficiency of an environmental impact statement [and] . . . review of the Final EIS could not be limited by the content of the administrative record").

The Fourth Circuit has followed a similar approach. See Webb v. Gorsuch, 699 F.2d 157, 159 n.2 (4th Cir. 1983) (allowing affidavits and reports from a state environmental agency and citing County of Suffolk for the proposition that "courts generally have been willing to look outside the record when assessing the adequacy of an EIS or a determination that no EIS is necessary").

156. See Sabine River Auth. v. United States Dep't of Interior, 951 F.2d 669, 678 (5th Cir. 1992) (noting that where "the district court has conducted an evidentiary hearing, and has drawn factual inferences and made credibility determinations, we must give great deference to the district court's conclusions"); Fritiofson v. Alexander, 772 F.2d 1225, 1230 (5th Cir. 1985) (noting that expert witnesses testified at trial on "various deleterious environmental effects" that could flow from a project); Sierra Club v. Hassell, 636 F.2d 1095, 1097-98 (5th Cir. 1981) (stating that "[a] reviewing court is to review the administrative records as well as other evidence to determine whether the agencies adequately considered the values set forth in NEPA and the potential environmental effects of the project before reaching a decision on whether an environmental impact statement was necessary" and referring to a court record containing "voluminous administrative records, depositions and affidavits, and a transcript of the testimony before the district court"). However, in at least one case, the Fifth Circuit has placed a limitation on extra-record review. See Sierra Club v. United States Army Corps of Eng'rs, 772 F.2d 1043, 1053 (5th Cir. 1985) (determining that "the 
cases, noting in a recent decision that a district court did not err in requiring plaintiffs to have "the burden of introducing affirmative evidence in court to prove that the assumptions underlying the ... environinental data [of an EIS] were incorrect."157 Courts within the Tenth Circuit have also accepted extra-record evidence in NEPA cases. ${ }^{158}$ This acceptance is not specifically premised on NEPA, however. A recent case, for example, noted that a court inay look outside the record to determine whether an agency "considered all relevant factors" or "where necessary to explam technical terms or coinplex subject matter."159

The Ninth Circuit appears to leave the acceptance of extra-record evidence largely to the discretion of the district courts. The Ninth Circuit has acknowledged exceptions to the record rule (but not exclusively in NEPA cases) ${ }^{160}$ (1) where "necessary to explain the agency's action," (2) to determine "whether the agency has considered all relevant factors or has explained its course of conduct or grounds of decision," (3) when the agency has relied on docuinents not in the record, and (4) when suppleinenting the record is "necessary to explain technical terms or

district court exceeded its power of review by evaluating and finding the [agency's] cxpert witness not credible," and thus "impermissibly substituted its judgment for that of the [agency]").

Use of extra-record evidence is also common within the district courts of the Fifth Circuit. See, e.g., Sierra Club v. Sigler, 532 F. Supp. 1222, 1228-29 (S.D. Tex. 1982) (allowing expert testimony on the importance of an affected bay and its wildlife and marine resources), aff'd in part, rev'd in part on other grounds, 695 F.2d 957 (5th Cir. 1983). But see Dardar v. LaFourchc Realty Co., 639 F. Supp. 1525, 1530 (E.D. La. 1986) ("Where an agency's decision is based on an administrative record, the decision should be viewed in light of that record.").

157. North Buckhead Civic Ass'n v. Skinner, 903 F.2d 1533, 1543 (11th Cir. 1990). The court also noted that the "district court conducted a four-day evidentiary hearing in which witnesses from the various federal and state agencies involved in the project testified about the preparation of the EIS." Id. at 1539. Plaintiff' witnesses also testified at that hearing. Id.

158. See Sierra Club v. Hodel, 848 F.2d 1068, 1090 n.17 (10th Cir. 1988) (noting that the district court's conclusions were based on "evidence and testimony adduced at trial"); Park County Resources Council, Inc. v. United States Dep't of Agric., 817 F.2d 609, 614 (10th Cir. 1987) (referring to the willingness of the district court to hear the testimony of eleven witnesses at a consolidated hearing and trial); Colorado Envtl. Coalition v. Lujan, 803 F. Supp. 364, 370-71 (D. Colo. 1992) (allowing plaintiffs to introducc testimony from a geological expert); Citizens for Envtl. Quality v. United States, 731 F. Supp. 970, 982-83 (D. Colo. 1989) (admitting expert affidavit to help the court to understand "the complex issues" presented by the case and to "illuminate the information contained in the administrative record"); Oklahoma Wildlife Fed'n v. United States Army Corps of Eng'rs, 681 F. Supp. 1470, 1489 (N.D. Okla. 1988) (allowing limited oral testimony on environmental and ecological impacts to "determine if there were significant oversights by the [agency] in its investigation"); National Indian Youth Council v. Andrus, 501 F. Supp. 649, 667 (D.N.M. 1980) (allowing evidence addressing the scientific methodology used in the E1S "to determine the general acknowledgment of that methodology within its associate substantive community"), aff'd, 664 F.2d 220 (10th Cir. 1981); Hiatt Grain \& Feed, Inc. v. Bergland, 446 F. Supp. 457, 467 (D. Kan. 1978) (allowing "extensive testimony and numerous exhibits" relevant to determining the adequacy of the EIS), aff'd, 602 F.2d 929 (10th Cir. 1979), cert. denied, 444 U.S. 1073 (1980).

159. Colorado Envtl. Coalition, 803 F. Supp. at 370.

160. Animal Defense Council v. Hodel, 840 F.2d 1432, 1436-37 (9th Cir. 1988), amended, 867 F.2d 1244 (9th Cir. 1989), discusses, but neither approves nor disapproves, the reasoning behind County of Suffolk. 
complex subject matter," and (5) when plaintiffs have made a showing of agency bad faith. ${ }^{161}$

Under these broad guidelines, district courts have routinely admitted extra-record evidence in NEPA cases. ${ }^{162}$ Indeed, in 1981, one district court noted that "the admission of extrinsic evidence on the issue of adequacy of an EIS appears to be the nornal practice in the Ninth Circuit."163 The Ninth Circuit, however, has generally also upheld district court decisions to exclude evidence where the agency appears to have weighed the relevant factors and where the administrative record adequately explains the agency's action. ${ }^{164}$

\section{The Recent Challenge to the NEPA Exception: Cronin and the Revival of the Record Rule}

While the acceptance of extra-record evidence in NEPA cases has been widespread in many circuits, some jurisdictions have been far more restrictive. For example, the Eighth Circuit has recently explained that new evidence should be allowed only to show the reasonableness of the agency's actions. ${ }^{165}$ As such, the court allowed only "testimony of an explanatory nature." 166

161. Id. at 1436-37.

162. See, e.g., Idaho Conservation League v. Mumma, 956 F.2d 1508, 1520 n.22 (9th Cir. 1992) (upholding the district court's decision to admit the affidavit of plaintiff's' expert on grounds that the "issues presented by this case are sufficiently complex with the affidavit, let alone without it, to justify using it as needed"); City of Davis v. Coleman, 521 F.2d 661, 675 (9th Cir. 1975) (noting that the municipality presented expert witnesses and studies); Natural Resources Defense Council, Inc. v. Duvall, 777 F. Supp. 1533, 1534 n.1 (E.D. Cal. 1991) (allowing new materials to show that the agency failed to consider all relevant factors); Blue Ocean Preservation Soc'y v. Watkins, 767 F. Supp. 1518, 1527 (D. Haw. 1991) (accepting affidavits by plaintiffs' experts); Portland Audubon Soc'y v. Lujan, 712 F. Supp. 1456, 1476 (D. Or. 1989) (stating that the court had previously "held an extensive evidentiary hearing in which evidence was presented by all parties as to the accuracy of the new information and the conclusions drawn from it"), aff'd in part, rev'd in part on other grounds, 884 F.2d 1233 (9th Cir. 1989), cert. denied, 494 U.S. 1026 (1990); Greenpeace U.S.A. v, Evans, 688 F. Supp. 579, 584 (W.D. Wash. 1987) (allowing introduction of zoologist's declaration); Village of False Pass v. Watt, 565 F. Supp. 1123, 1141 (D. Alaska 1983) (allowing introduction of a biological opinion), aff'd, 733 F.2d 605 (9th Cir. 1984).

163. No Oilport! v. Carter, 520 F. Supp. 334, 346 (W.D. Wash. 1981).

164. See Friends of the Payette v. Horseshoe Bend Hydroelectric Co., No. 92-36611, 1993 WL 75967, at *7 (9th Cir. Mar. 19, 1993) (upholding the district court's decision to exclude, on the grounds of redundancy, the testimony of 13 of plaintiff's 14 witnesses); Havasupai Tribe v. Robertson, 943 F.2d 32 (9th Cir. 1991) (upholding the district court's decision to limit its review to the administrative record), cert. denied, 112 S. Ct. 1559 (1992); Animal Defense Council v. Hodel, 840 F.2d 1432, 1436-38 (9th Cir. 1988) (upholding the district court's limiting the scope of review to the administrative record and prohibiting discovery), amended, 867 F.2d 1244 (9th Cir. 1989); Friends of the Earth v. Hintz, 800 F.2d 822, 828-29 (9th Cir. 1986) (upholding the district court's order quashing plaintiffs' deposition notices).

165. See Missouri Coalition for the Env't v. Corps of Eng'rs, 866 F.2d 1025, 1031 (8th Cir. 1989).

166. Id.; see also Monarch Chem. Works, Inc. v. Exon, 466 F. Supp. 639, 647 (D. Neb. 1979) (stating that extra-record evidence is to be restricted to that evidence necessary for evaluating the reasonableness of the agency's decision). Earlier district court opinions in the Eighth Circuit seemed 
There are also indications that the First Circuit may be moving towards a more restricted analysis of extra-record evidence. In Valley Citizens for a Safe Environment v. Aldridge, ${ }^{167}$ the court asserted only three exceptions to the record rule: (1) where the agency knew about an important matter (which the challenging party did not know about) but the EIS ignored, (2) where the agency improperly relied upon secret information, or (3) where such evidence would aid the court in "understanding highly techmical, environmental matters."168

It is the Seventh Circuit's recent opinion in Cronin v. United States Department of Agriculture, ${ }^{169}$ however, that most strikingly restricts the introduction of extra-record evidence in NEPA cases. In Cronin, plaintiff environmental groups challenged a timber sale by the U.S. Forest Service under NEPA. After holding an evidentiary hearing, the district court denied plaintiffs' request for a preliminary injunction. ${ }^{170}$ Upon review, the circuit court, in an opinion by Judge Posner, found the holding of an evidentiary hearing to be a "puzzle."171 Judge Posner explained that district courts, when reviewing administrative actions, should take evidence only in the rarest of circumstances. ${ }^{172}$ If the agency's review of the issues presented "was inadequate to develop the facts necessary to a sound decision,"173 "[t]he proper judicial remedy" is to remand to the agency to conduct further hearings. ${ }^{174}$ In the end, a court should look beyond the record only in an "emergency"-i.e., where there is "no record and no feasible method of requiring the agency to compile one in time to protect the objector's rights."175

The circuit asserted two major foundations as supporting this result. First, courts should respect the technical expertise of the agencies:

Confining the district court to the record compiled by the administrative agency rests on practical considerations that deserve respect. Administrative agencies deal with technical questions, and it is imprudent for the generalist judges of the federal district courts and courts of appeals to consider testimonial and documentary evidence bearing on those questions unless

to accept less restrictive rules goveruing extra-record evidence. See, e.g., Residents in Protest-I35E v. Dole, 583 F. Supp. 653, 662 (D. Minn. 1984) (accepting without comment the testimony of both parties' experts before the court); Como-Falcon Coalition v. United States Dep't of Labor, 465 F. Supp. 850, 856 n.l (D. Minn. 1978) (recognizing the need for extra-record evidence in NEPA cases), aff'd, 609 F.2d 342 (8th Cir. 1979), cert. denied, 446 U.S. 936 (1980).

167. 886 F.2d 458 (1st Cir. 1989).

168. Id. at 460 .

169. 919 F.2d 439 (7th Cir. 1990).

170. Id. at 443.

171. Id.

172. Id. at 443-44.

173. Id. at 444.

174. Id.

175. Id. 
the evidence has first been presented to and considered by the agency. ${ }^{176}$

Second, the court recognized the primary role of the administrative record in determining the lawfulness of the administrator's decision. "All that the plaintiffs are entitled to do in the courts is to try to persuade the district judge and then us, on the basis of the evidence that was before the forest supervisor when he made his decision, that the decision is unlawful."177

Cronin creates an attractive bright-line rule, restricting district courts from taking extra-record evidence in appeals of adninistrative action except in the most egregious cases. While Cronin ignores County of Suffolk and the long hine of NEPA cases that follow, ${ }^{178}$ Cronin fits easily within the holdings of Camp and Lorion, both of which urge reniand to the agency if the administrative record is inadequate. ${ }^{179}$ Thus, it is perhaps less surprising that district courts, not only in the Seventh Circuit, ${ }^{180}$ but even in circuits with their own well-developed case law on the issue, have rehed on Cronin in challenges to NEPA documents. ${ }^{181}$ This reliance may also, however, reflect the failure of the courts, at least since County of Suffolk, to address carefully the particular evidentiary issues that arise in NEPA cases.

III

ANALYSIS OF THE NEPA EXCEPTION

Judicial review has played an enormous role in the implementation of NEPA. ${ }^{182}$ NEPA is important mostly because it is legally binding,

176. Id.

177. Id. at 445 .

178. It is interesting to note that an earlier Seventh Circuit NEPA case, Van Abbema v. Fornell, 807 F.2d 633 (7th Cir. 1986), did cite Suffolk for the proposition that "in certain cases admission of new evidence is proper, even desirable, in assisting the court in its evaluation of the sufficiency of an administrative record." Id. at 643 . In that case, however, the Seventh Circuit upheld the district court's decision not to admit the testimony of four witnesses "where the administrative record alrcady contained significant material from each of the four." Id.

179. In fact, Cronin specifically cites Lorion as support for its argument to remand to the agency. Cronin, 919 F.2d at 443, 444. For a discussion of Camp and Lorion, as well as their role in the development of the record rule, see supra text accompanying notes 87-100.

180. See Sierra Club v. Marita, 769 F. Supp. 287, 291-93 (E.D. Wis. 1991) (citing Cronin as support for denying plaintiffs' motion to supplement the administrative record); Village of Palatine v. United States Postal Serv., 756 F. Supp. 1079, 1083 (N.D. Ill. 1991) (same).

181. See Inland Empire Pub. Lands Council v. Schultz, 807 F. Supp. 649, $651-52$ (E.D. Wash. 1992) (citing Cronin and limiting review to the administrative record); Sierra Club v. Robertson, 784 F. Supp. 593, 601 (W.D. Ark. 1991) (citing Cronin and stating that plaintiffs were "simply entitled to have the district court review the administrative record upon which the Forest Service based its decision and determine whether, applying an arbitrary and capricious standard, the agency action was legal"). Although unclear from the opinion itself, Inland Empire was brought under NEPA (among other statutes). Telephone Interview with Mark Wilson, attorney for Inland Empire (Apr. 9, 1993).

182. See Rosenbaum, supra note 134, at 16-17, 48 (discussing the role of the courts in helping 
and these legal binds are meaningful only to the extent that they are enforceable against the agencies. ${ }^{183}$ Determining the appropriate role for courts reviewing NEPA decisions, however, is coinplicated by the lack of discussion of judicial review either in NEPA or in its legislative history. ${ }^{184}$ Nevertheless, Congress so far appears to have been content to allow judicial orders to shape NEPA's development. ${ }^{185}$

Many courts have found the record rule particularly unsuited to reviewing NEPA documents. Because an agency's duty under NEPA is to create a coinprehensive discussion of potential environinental inpacts, its failure to meet this duty will generally not be apparent from the agency-created record. In addition, the arguinents that are generally put forward to legitinize the use of the record rule are unpersuasive in the context of NEPA. First, the record rule assumes agencies' expertise in resolving technical issues within their jurisdiction. Second, it reflects the judiciary's respect for agency independence in exercising decisionmaking authority delegated to the agencies by Congress. Third, the record rule recognizes agency proceedings as legitinate and adequate fact-finding forums because of the opportunities for public input. Finally, the record rule prevents plaintiffs from "sandbagging" the agency by introducing evidence in court which the agency never had the opportunity to address. When applied to NEPA cases, however, each of the concerns underlying the record rule is minimized.

\section{A. The Failure to Consider Relevant Factors}

Failure to consider relevant factors is the very essence of agency arbitrariness. ${ }^{186}$ Thus, one of the most common exceptions to the record

to create and enforce NEPA); LEAH J. WILDS, UNDERSTANDING WHO WINS: ORGANIzATIONAL BehaVior AND ENVIRONMENTAL Politics 27 (1990) (noting that "NEPA became the most frequently-litigated of the environmental policies passed during the Sixties and Seventies").

183. CEQ regulations hold that the courts, together with the executive branch and the agencies, "share responsibility for enforcing the Act so as to achieve the substantive requirements" for compliance. 40 C.F.R. § 1500.1(a) (1992). See also ANDERSON, supra note 116, at 276 ("NEPA prescribed administrative reform through a set of requirements and procedures that strongly reinforced the traditional goals of judicial review.").

Without strict judicial review, a danger that agencies will treat NEPA's goals lightly arises. Agencies may "prepare apologies rather than EISs." Mary H. O'Brien, NEPA as It Was Meant to Be: NCAP v. Block, Herbicides, and Region 6 Forest Service, 20 ENVTL. L. 735, 743 (1990).

184. ANDERSON, supra note 116, at 13-14, 16. The only clear reference to any kind of judicial review in NEPA's legislative history occurs in the Senate report on NEPA, which states that "thc 'environmental' desires of the American people [must be defined] in operational terms that the President, Government agencies at all levels, the courts, private enterprise, and the public can consider and act upon." Id. at 13 (quoting SENATE COMM. ON INTERIOR \& INSULAR AFFAIRS, National Environmental Policy ACt of 1969, S. Rep. No. 296, 9lst Cong., 1st Sess. 13 (1969)).

185. See Kleppe v. Sierra Club, 427 U.S. 390, 421 (1976) (Marshall, J., concurring in part and dissenting in part) (remarking that "this vaguely worded statute seems designed to serve as no morc than a catalyst for development of a 'common law' of NEPA").

186. See Motor Vehicle Mfrs. Ass'n of the United States v. State Farm Mut. Auto. Ins. Co., 463 
rule in all types of cases has been the courts' willingness to allow extrarecord evidence to prove that the agency ignored relevant factors that it was required to consider. ${ }^{187}$ Such an exception is especially important in NEPA cases. Under NEPA, the primary role that Congress assigned federal agencies is not that of a pohcy-maker or umpire, but that of a careful investigator. ${ }^{188}$ The agency's role is not to justify a particular policy decision, but to create a record of potential environmental impacts.

Errors in NEPA documents, however, are frequently errors of oinission that will not appear on the face on the record. ${ }^{189}$ Since the agency's only duty under NEPA is to analyze relevant environinental impacts, the fact that a given impact is discussed in an EA or EIS will generally meet NEPA's requireinents unless the discussion is challenged by an outsider. This presents a problem for a judge attempting to apply the record rule: even if nobody comments on a draft EIS, for example, there inust be some minimum standard by which a court can judge the adequacy of the final EIS. ${ }^{190}$

U.S. 29, 43 (1983) (defining an agency rule as arbitrary and capricious where, inter alia, "the agency has relied on factors which Congress has not intended it to consider [or] entirely failed to consider an important aspect of the problem"); Bowman Transp., Inc. v. Arkansas-Best Freight Sys., 419 U.S. 281,285 (1974) (asserting that the arbitrary and capricious standard involves a review of whether the agency considered all relevant factors in its decisionmaking); Citizens to Preserve Overton Park v. Volpe, 401 U.S. 402,416 (1971) (same).

187. See Stark \& Wald, supra note 10, at 346-47.

188. See Baltimore Gas \& Elec. Co. v. Natural Resources Defense Council, Inc., 462 U.S. 87, 97 (1983) (echoing the position of the Vermont Yankee Court); Vermont Yankee Nuclear Power Corp. v. Natural Resources Defense Council, Inc., 435 U.S. 519, 551, 553 (1978) (noting that "NEPA places upon an agency the obligation to consider every significant aspect of the environmental impact of a proposed action"); Grazing Fields Farm v. Goldschmidt, 626 F.2d 1068, 1073 (1st Cir. 1980) ("NEPA expressly places the burden of compiling information on the agency so that the public and interested government departments can conveniently monitor and criticize the agency's action."); Greene County Planning Bd. v. Federal Power Comm'n, 455 F.2d 412, 420 (2d Cir. 1972) (holding that the "primary and nondelegable responsibility" for fulfilling NEPA's investigative process requirements lies with the agency), cert. denied, 409 U.S. 849 (1972); Calvert Cliffs' Coordinating Comm., Inc. v. United States Atomic Energy Comm'n, 449 F.2d 1109, 1119 (D.C. Cir. 1971) ("The primary responsibility for fulfilling [NEPA's] mandate lies with the [agency]. Its responsibility is not simply to sit back, like an umpire, and resolve adversary contentions at the hearing stage. Rather, it must itself take the initiative of considering environmental values at every distinctive and comprehensive stage of the process beyond the staff's evaluation and recommendation.").

189. An overlooked environmental impact by its very nature will not be in the record unless it has becn raised by an outside commenter during the administrative process, and even then it may be presented in insufficient detail to provide legal proof of its significance. See Como-Falcon Coalition, Inc. v. United States Dep't of Labor, 465 F. Supp. 850, 856 n.1 (D. Minn. 1978) ("If the federal agency has overlooked or inadequately assessed a possible adverse environmental impact, it is unlikely that the deficiency will be apparent from examination of the record itself. Given the scheme of NEPA and the scrutiny with which the judiciary must eye negative assessments of environmental impact, a reviewing court cannot be restricted to the administrative record."), aff'd, 609 F.2d 342 (8th Cir. 1979), cert. denied, 446 U.S. 936 (1980).

190. The courts have not fully resolved whether, in overturning an agency decision under NEPA, the correct standard is one of arbitrariness, reasonableness, good faith, or a combination 
Under the record rule, courts have no effective means of determining whether an agency fulfilled the congressional mandate to analyze all significant environmental effects. Instead, they must judge the adequacy of NEPA documents by determining whether the agency responded to issues brought to its attention by the public during the administrative process. Such a subjective standard, judging the agency's review by how it dealt with information provided by outsiders, is inappropriate under a statute that forces upon agencies a mandatory duty to assess environmental impacts and to educate themselves and the public. ${ }^{191}$

Because NEPA applies to a vast array of federal actions, it does not contain a hist of relevant factors that could aid the court in determining whether agency action is arbitrary. CEQ regulations provide some guidelines, ${ }^{192}$ but they are certainly not exhaustive. Courts must judge the reasonableness of an agency's NEPA review by determining whether it considered relevant factors. Under the record rule, the scope of relevant factors is limited to those considered by the agency. This circular process, except for the most extreme cases of abuse, amounts to no judicial oversight at all. ${ }^{193} \mathrm{~A}$ court that allows plaintiffs to introduce new evidence, in contrast, may make a far more complete review of the adequacy of an agency's discussions and conclusions.

\section{B. The Presumption of Expertise}

By the late 1960s, Congress had begun to realize that helter-skelter development and destruction of natural resources were threatening the

thereof. See, e.g., Marsh v. Oregon Natural Resources Council, 490 U.S. 360, 376 (1989) (applying the arbitrary and capricious standard to decision not to supplement an EIS); Holy Cross Wilderness Fund v. Madigan, 960 F.2d 1515, 1522 (10th Cir. 1992) (measuring the adequacy of an EIS by determining whether there has been a "reasonable, good faith, objective presentation of' the topics NEPA requires an EIS to cover") (quoting Johnston v. Davis, 698 F.2d 1088, 1091 (10th Cir. 1983)); Stein v. Barton, 740 F. Supp. 743, 748 (D. Alaska 1990) (employing a reasonableness standard). This Comment is concerned, however, not so much with what standard of review to apply, but with the closely related question of the basis of that review.

As Judge Leventhal has suggested, there might be forums other than the courts for ensuring effective review of NEPA decisions, i.e., Congress and superagencies in the executive branch. Leventhal, supra note 98, at 515. Leventhal points out, however, that these forums are used infrequently: Congress rarely acts on NEPA issues, while CEQ and EPA play only a minor role in reviewing NEPA decisions. Id. at 515-16. Thus the burden of NEPA review has fallen almost exclusively on the judiciary.

191. See Coalition for Canyon Preservation v. Bowers, 632 F.2d 774, 782 (9th Cir. 1980) ("[S]ubjective good faith is not the test for determining the adequacy of an EIS. The test is an objective one.")

192. See, e.g., 40 C.F.R. $\$ 1508.27$ (1992) (providing a detailed definition of what constitutes "significantly" as it is used in NEPA).

193. No scope of review or standard of agency decisionmaking alleviates this central circularity. Thus, the question of whether the agency decisionmaker explored all possible avenues, made a good faith effort, or simply refrained from acting like an "arbitrary and capricious lunatic," see SHAP1RO, supra note 4 , at 74 , will not necessarily reach the question of whether the agency excluded relevant factors if judicial review is based only on the administrative record. 
nation's natural and human enviroument. ${ }^{194}$ NEPA was intended as a check on thoughtless governmental action and was designed to force all federal agencies-regardless of their primary mission-to consider the environmental impacts of their actions. ${ }^{195}$ NEPA is thus umique im that it places significant duties on all federal agencies-duties which are procedural in nature but which require substantive knowledge in the area of environmental science. Because NEPA must be implemented by all federal agencies, however, the usual automatic judicial deference to agency claims of expertise is unwarranted. In addition, because NEPA is designed to expose the risks of an agency's proposed project, an agency may have hittle incentive to prepare an adequate NEPA review. ${ }^{196}$ Allowing plaintiffs a chance to admit extra-record evidence may be the only means of overcommg this inherent bias.

\section{The Broad Mandate of NEPA}

The record rule assumes that courts should not undermine agency functions by replacing agencies' expert opinions with those of a less experienced judge. By encouraging judicial deference to agency expertise, the record rule recognizes the advantages of a coherent and informed agency decisionmaking process.

But while the agency expertise rationale for the record rule may accord with a traditional model of judicial review of agency action, the presumption of agency expertise in NEPA cases is misplaced. NEPA's mandate to all federal agencies ensures that many agencies without environmental expertise will be performing actions under NEPA.

194. In explaining the need for NEPA legislation, the House Report cited a New York Times editorial:

"By land, sea, and air, the enemies of man's survival relentlessly press their attack. The most dangerous of all these enemies is man's own undirected technology. The radioactive poisons from nuclear tests, the runoff into rivers of nitrogen fertilizers, the smog from automobiles, the pesticides in the food chains, and the destruction of topsoil by strip mining are examples of the failure to foresee and control the untoward consequences of modern technology."

H.R. REP. No. 387, 91st Cong., 1st Sess. 6 (1969), reprinted in 1969 U.S.C.C.A.N. 2751, 2753. The report noted that the editorial "may understate the complexity and urgency of the challenge" and recognized the difficulty of addressing these issues. "The problem is deep, and it touches on practically every aspect of everyday life .... It is a problem to which Presidents have addressed themselves with increasing concern in recent years, and it is a problem which we can no longer afford to treat as of secondary importance." Id.

195. See Richard A. LirofF, A National Policy for the Environment 80-82 (1976) (noting that NEPA's "goal was to overhaul fundamentally an incremental decision-making process in which the pursuit of narrow economic goals had obscured the need to weigh environmental impact").

196. See Daniel A. Dreyfus \& Helen M. Ingram, The National Environmental Policy Act: A View of Intent and Practice, 16 NAT. ResourCes J. 243, 251, 255 (1976) (noting that EISs "were invented in response to the anticipated administrative indifference or outright hostility toward the environmental council and the environmental policy statement" and explaining that the original drafters contemplated a role for the courts because "[t]he temptation for agency officials to understate the adverse environmental consequences of favorite proposals was recognized"). 
Environmental review is often tangential or unrelated to an agency's primary mission. ${ }^{197}$ In addition, although some government agencies employ staff who have experience in studying environmental impacts, other agencies that prepare NEPA documents may have developed little expertise in environmental science. ${ }^{198}$ Thus, despite what often appears to be the judiciary's almost instinctive deference to governmental expertise, ${ }^{199}$ some courts have acknowledged that not all agencies have special competency to review the environmental effects of their actions. ${ }^{200}$

197. See CEQ 20TH ANNUAL REPORT, supra note 136, app. B at 392 (noting numerous NEPA suits against agencies such as the Army Corps of Engineers, the Department of Transportation, the Interstate Commerce Commission, the Department of Housing and Urban Development, and the Department of the Navy).

198. While the Environmental Protection Agency may be a significant exception, many missionoriented agencies may place a low priority on developing a strong corps of professionals schooled in conducting environmental review. See Serge Taylor, Making Bureaucracies Think: The ENVIRONMENTAL IMPACT STATEMENT STRATEGY OF ADMINISTRATIVE REFORM 252-53 (1984) (noting that while NEPA is "likely to increase the agency's incentives to recruit professionally welltrained-hence probably environmentally committed-EIS analysts," such "environmental specialists will always be a minority in these mission-oriented agencies").

Some agencies have dealt with their lack of expertise by hiring private contractors as provided by 40 C.F.R. $\S 1506.5(\mathrm{c})$ (1992). While contracting out NEPA duties may be seen as a valid means for agencies to attempt to compensate for their lack of experience, it nevertheless undercuts the presumption of agency expertise. The hiring of private contractors to prepare NEPA documents is common. See, e.g., Citizens Against Burlington, Inc. v. Busey, 938 F.2d 190, 192 (D.C. Cir. 1991) (noting that Toledo-Lucas County Port Authority hired a private consulting organization to prepare an EA to submit to the Federal Aviation Authority), cert. denied, 112 S. Ct. 616 (1991); Sierra Club v. United States Army Corps of Eng'rs, 701 F.2d 1011, 1017-18 (2d Cir. 1983) (discussing how the administrative entity that issued the draft EIS and final EIS for a highway project was "comprised almost entirely of outside firms"); Sierra Club v. Sigler, 695 F.2d 957, 963 n.3 (5th Cir. 1983) (noting that most, if not all, the preparation on the draft EIS and final EIS "was done by the private consulting firm hired by the applicants," despite the fact that the consulting firm had a stake in the project whieh it was evaluating). For a discussion of the problems that can arise from delegating NEPA responsibilities, see Michael E. Lackey, Jr., Misdirecting NEPA: Leaving the Definition of Reasonable Alternatives in the EIS to the Applicants, 60 GEO. WASH. L. REV. 1232 (1992); Robert P. Frank, Comment, Delegation of Environmental Impact Statement Preparation: A Critique of NEPA's Enforcement, 13 B.C. ENVTL. AFF. L. REV. 79 (1985).

199. See, e.g., Marsh v. Oregon Natural Resources Council, 490 U.S. 360, 376-77 (1989) (determining that the ease involved "a classic example of a factual dispute the resolution of which implicates substantial agency expertise" and determining that "[b]ecause analysis of the relevant documents 'requires a high level of technical expertise,' we must defer to 'the informed discretion of the responsible federal agencies' ") (citing Kleppe v. Sierra Club, 427 U.S. 390, 412 (1976)); Baltimore Gas \& Elec. Co. v. Natural Resources Defense Council, Inc., 462 U.S. 87, 103 (1983) ("When examining this kind of scientific determination ... a reviewing court must generally be at its most deferential.")

This pattern of deference may help explain NEPA's poor record (from plaintiffs' perspective) in the Supreme Court. The Supreme Court has never ruled against the goverument or in favor of a plaintiff representing an environmental interest group in the dozen NEPA cases that have come before it. See David C. Shilton, Is the Supreme Court Hostile to NEPA? Some Possible Explanations for a I2-0 Record, 20 ENVTL. L. 551, 553 (1990).

200. See Park County Resources Council, Inc. v. United States Dep't of Agric., 817 F.2d 609 (10th Cir. 1987). In Park County, the court noted:

[D]eference to agency expertise is inapplicable in the NEPA context. The deference envisioned under this rationale is appropriate when the disputed issue is one expressly delegated to an agency that deals exclusively with the area and so has refined an expertise 
This lack of agency expertise is particularly problematic given the technical nature of the documents required by NEPA. Other than the ultimate choice of whether or not a proposed project should go forward, most agency decisions throughout the NEPA process are supposed to be scientific rather than political in nature. ${ }^{201}$ Predicting environmental impacts is inherently speculative, and therefore difficult. ${ }^{202}$ A lack of environmental expertise may cause an agency madvertently to ignore relevant factors or to overlook an important body of information in reaching a decision. ${ }^{203}$

CEQ atteinpts to coinpensate for this possible lack of agency expertise by requiring other federal agencies possessing special expertise on a given environmental impact to comment on draft EISs, ${ }^{204}$ and courts may take such comments very seriously when they are substantial. ${ }^{205}$ Given the economic constraints on governmental agencies, however, such reviews may prove impractical or limited. ${ }^{206}$ In addition, there are few other mandatory controls-such as formal proceedings, significant

\footnotetext{
in its nuances. All federal agencies are required under NEPA to prepare an EIS if a proposed action meets the statutory criteria. No single agency has expertise in determining whether an EIS is statutorily mandated in a given instance. NEPA imposes duties on agencies; agencies do not exist to administer NEPA. Hence, courts are equally well-suited to examine the issue of whether a proposed action is a major federal action significantly affecting the environment.
}

Id. at 620; see also City of Irving v. Federal Aviation Admin., 539 F. Supp. 17, 34 (N.D. Tex. 1981) (noting that the Federal Aviation Administration "has no expertise or specialized knowledge in determining when an EIS is required under NEPA").

201. CEQ regulations state that in determining whether an effect is significant, the agency should consider, among other factors, "[t] $]$ he degree to which the proposed action affects public health or safety," "[t]he degree to which the possible effects on the human environment are highly uncertain or involve unique or unknown risks," whether the action is related to other actions that will have "cumulatively significant impacts," and "[t]he degree to which the action may adversely affect an endangered or threatened species or its habitat." 40 C.F.R. $\S 1508.27$ (1992).

202. See Paul J. Culhane, NEPA's Impacts on Federal Agencies, Anticipated and Unanticipated, 20 ENVTL. L. 681, 694-95 (1990) (discussing the failure of most EISs to make accurate and quantified predictions).

203. For example, in People ex rel. Van de Kamp v. Marsh, 687 F. Supp. 495 (N.D. Cal. 1988), the Port of Oakland had applied to the Army Corps of Engineers for a permit to fill wetlands to expand airport facilities. Id. at 497. The court found that the Corps had overlooked a number of significant environmental effects in its EA. Id. at 497-500. Although the site was an "important part of the migration trip for ... migratory birds," the Corps "did not have adequate information regarding the numbers of birds." Id. at 499. Its studies on an endangered mouse species were inaccurate and its decision was "not based on the most up-to-date information available to the Corps." Id. The Corps failed to evaluate whether the project would increase the pollution of the wetlands and failed to verify the data on noise levels that it relied upon. Id. It did not evaluate the impacts of increased pollutant run-off into the San Francisco Bay. Id. at 500. Finally, the Corps failed to examine the cumulative impacts of the proposed action on the local environment. Id.

204. 40 C.F.R $\$ 1503.2$ (1992).

205. See Michael C. Blumm \& Stephen R. Brown, Pluralism and the Environment: The Role of Comment Agencies in NEPA Litigation, 14 HARv. ENVTL. L. REV. 277, 281-82 (1990) (concluding that "courts are very likely to reach conclusions about NEPA compliance that are consistent with the position advanced by the comment agency").

206. See Jeanne N. Clarke \& Daniel. McCool, Staking Out the Terrain: Power Differentials Among Natural Resource Management Agencies 85-86 (1985) (noting that 
appeal opportunities, or neutral expert review panels-to ensure the adequacy of NEPA review. ${ }^{207}$ The public comment period is also unlikely to fill the gaps in agency expertise. ${ }^{208}$

A strict apphication of the record rule in the NEPA context can be effective only if agencies are presumed to have the expertise to put together a competent analysis of environmental impacts. Such a presumption is unrealistic in NEPA cases where agency expertise in environmental science may vary widely. Where the usual deference to agency expertise is no longer appropriate, courts should be more willing to go outside the record to measure the adequacy of an agency's conclusions. $^{209}$

\section{Incentives for Inadequate NEPA Review}

The disjuncture between the overall mission of an agency and the obhigations imposed on that agency under NEPA does more than call into question the reliability of an agency's technical conclusions in performing its NEPA obligations. It also creates the possibility that agencies may have an interest in downplaying potentially significant environmental risks.

NEPA is often an impediment to the primary mission of an admimistrative agency. ${ }^{210}$ By exposing the environmental problems of its

the understaffed and low-budget Fish and Wildlife Service was inundated with EISs from other agencies during the early years).

207. Nor are courts free to demand new procedures to ensure that a more substantial review takes place. See supra notes 101-04 and accompanying text (discussing the Supreme Court's decision in Vermont Yankee Nuclear Power Corp. v. Natural Resources Defense Council, Inc., 435 U.S. 519 (1978)). The Vermont Yankee Court specifically held that "NEPA cannot serve as the basis for a substantial revision of the carefully constructed procedural specifications of the APA" and the agency need employ only the "statutory minima" demanded by the APA or NEPA. Vermont Yankee, 435 U.S. at 548. As long as an agency has allowed for notice and comment and any other public participation requirements mandated by applicable agency or CEQ regulations, the court cannot demand additional procedures for reviewing evidence. Id. at 549 (asserting that the Court cannot "impose upon the agency its own notion of which procedures are "best" ").

208. See infra Section III.D.

209. While courts also may not have expertise in environmental areas, this should not excludc judicial review of the merit of EISs, which are supposed to be accessible to and understandable by the public. See Philip M. Ferester, Revitalizing the National Environmental Policy Act: Substantive Law Adaptions from NEPA's Progeny, I6 HARV. ENVTL. L. REV. 207, 266 (1992). The author notes that it should not be problematic for "courts to compare the evidence in the EIS or agency record with the evidence supporting alternative decisions. Comparing the merits of different kinds of evidence, even evidence of a scientific nature, falls well within the realm of ordinary judicial experience." Id.

210. This danger was recognized in a rather ironic manner in Residents in Protest-I-35E v. Dole, 583 F. Supp. 653 (D. Minn. 1984). Plaintiffs alleged that two officials responsible for preparing and approving the EIS on a segment of interstate highway had a precxisting bias in favor of the project. Id. at 661 . The court agreed that the officials "may not have been subjectively impartial." Id. It excused the officials, however, stating that "NEPA does not require, or even contemplate, that decision makers will be completely impartial. In fact, NEPA assumes that institutional biases will exist and requires that an EIS be prepared to insure that the decision maker cannot avoid coming to grips with the environmental consequences of the proposed action." Id. at 
proposed project, the agency is likely to invite objections to its own desired action. Agencies therefore may be less motivated to produce a comprehensive record of environmental risks than they would be to produce a record in support of their own enforcement or rulemaking decisions. ${ }^{211}$ The result is an unusually high risk of self-serving "expert" conclusions in NEPA cases. ${ }^{212}$

Application of the record rule to plaintiffs in such circumstances may lead agencies to be less vigilant in preparing comprehensive and balanced NEPA documents. Under the record rule, the NEPA documents

661-62 (citation omitted); see also Natural Resources Defense Council, Inc. v. SEC, 606 F.2d 1031, 1048-49 (D.C. Cir. 1979) (noting that "courts, in cases involving NEPA's environmental impact statement requirement, have exercised particularly stringent review of procedural compliance with NEPA, at least when the agency involved does not include environmental protection within its primary mission," and recognizing that "environmental concerns to some extent run counter to the SEC's primary mandate of financial protection of investors, and that there is here a substantial role for the court to play in ensuring that NEPA's procedural commands are carried out in full measure by the SEC') (citations omitted).

211. See, eg., Lynton K. Caldwell, $A$ Constitutional Law for the Environment: 20 Years with NEPA Indicates the Need, 31 ENV'T 6, 25-26 (1989) (noting that "[w]hen controversial projects are proposed ... there is often a strong desire on the part of agency staff that environmental impact statements should appear to support agency preferences").

The significant empirical data on agency responses to NEPA that occurred in the 1970s suggests similar conclusions. For example, Taylor notes that the leadership of an agency may be poorly motivated to expose their errors to public scrutiny, in part because "they may be deeply committed to an organization's traditional programs and ill inclined to take a broader perspective." TAYLOR, supro note 198, at 28. Taylor also notes that the Corps of Engineers, especially in the early days of implementing NEPA, would keep its own environmental experts "out of the planning process" and exclude them from "effective participation" due to political constraints and structural incentives disfavoring environmentalist input. Id. at 95-96.

Taylor observed that the Forest Service exercised even more effective control over its environmental professionals, explaining that "[i]f an environmental specialist develops a reputation for uncooperativeness with the management-oriented professionals, he can always be ... put to work on carefully circumscribed studies for the Unit Planning team without being a full participant in the discussion of EIS alternatives and mitigation measures, or even be assigned non-EIS work." Id. at 109; see also LIROFF, supra note 195, at 141 (noting that even those mission-oriented agencies that achieved procedural compliancc with NEPA may not have incorporated environmental values into their decisionmaking).

Other commentators have stated that "[a] fundamental problem with the EIS process is that the agency which is responsible for a projeet (and thus often has a vested interest in the project) is also responsible for preparing the impact statement and responding to comments on the draft EIS." $H$. Paul Friesema \& Paul J. Cuthane, Social Impacts, Politics, and the Environmental Impact Statement Process, 16 NAT. Resources J. 339, 352 (1976). The authors assert that "[i]t is not uncommon for agencies to ignore or misinterpret the detailed and apparently compelling comments they receive, leaving the substance of the final EIS essentially unchanged from the draft." Id.

212. See JAFFE, supra note 1 , at 580 (discussing experts in general and noting that "[t]he expert is often ... seeking to advance his conception of policy, and to give it greater sanctity by embodying it in the secming objectivity of an 'expert discipline" "); see also Burlington Truck Lines v. United States, 371 U.S. 156, 167 (1962) ("Expert discretion is the lifeblood of the administrative process, but 'unless we make the requirements for administrative action strict and demanding, expertise, the strength of modern goverument, can become a monster which rules with no practical limits on its discretion.'" (quotation omitted)); EDLEY, supra note 1, at 85-86 (1990) (weighing the positive qualities of objectivity, professionalism, and rationality associated with agency expertise against the dangers of scientific isolation and unresponsiveness). 
will be judged only against the material before the agency at the time it makes its decision. The record rule therefore may create incentives for agencies to prepare their environmental reviews reactively, waiting for outside groups to raise questions about significant impacts. ${ }^{213}$ The agency still has a duty to consider impacts that will significantly affect the environment, but this duty will not be judicially enforceable unless the existence of these impacts is clear from the record. In other words, an agency may safely ignore all impacts except those which potential plaintiffs have raised before them with a degree of specificity that would convince the average judge. As one court recognized, to make execution of the agency's duty of environmental review "contingent upon the vigilance and diligence of particular environmental plaintiffs would encourage attempts by agencies to evade their important responsibilities. It is up to the agency, not the public, to ensure compliance with NEPA in the first instance." 214

To discourage this kind of reactive environinental review, some courts have prevented agencies from introducing extra-record evidence. ${ }^{215}$ Such a rule, however, should not be used to bar plaintiffs from presenting extra-record evidence. One court has noted that its acceptance of extra-record evidence was not a "two-way street," justifying this conclusion by reference to the incentive structure built into NEPA:

First, a plaintiff who demonstrates that the agency developed an inadequate record should be afforded an opportunity, in essence, to develop that record. Second, if this were not the rule, an agency would have little incentive to prepare an adequate and

213. See TAYLOR, supra note 198, at $256 \mathrm{n} .^{*}$ (noting that in the EPA sewage treatment plant construction grant program in the 1970s, "regional office EIS writers often had instructions to do [EIS's] 'first' (that is, only) on projects which environmental groups had already criticized for having adverse impacts, and to concentrate on publicly noted impacts, thereby avoiding instigating opposition to other potential problems").

214. City of Davis v. Coleman, 521 F.2d 661, 678 (9th Cir. 1975).

215. See Citizen Advocates for Responsible Expansion v. Dole, 770 F.2d 423, 434 (5th Cir. 1985) (stating that "an agency's decision not to file an EIS will be analyzed on the basis of the agency's findings and the information necessarily before the agency at that time"); California v. Block, 690 F.2d 753, 765 (9th Cir. 1982) (holding that worksheets which were not easily accessible to the public could not be considered in determining the adequacy of an EIS); Grazing Fields Farm v. Goldschmidt, 626 F.2d 1068, 1069 (1st Cir. 1980) (holding that information in the administrativc record but not incorporated into the EIS cannot be used to show the adequacy of the EIS); Natural Resources Defense Council, Inc. v. Morton, 458 F.2d 827, 836 (D.C. Cir. 1972) (holding that an insufficient statement could not be justified by extra-record evidence since the EIS "must set forth the material contemplated by Congress in form suitable for the enlightenment of the others concerned"); Friends of the Earth v. Hall, 693 F. Supp. 904, 935 n.19 (W.D. Wash. 1988) (noting the agency's "attempts to improperly supplement the administrative record with post hoc scientific studies"). But see Sierra Club v. Marsh, 907 F.2d 210, 212 (1st Cir. 1990) (allowing "supporting affidavits [from the agency] designed to demonstrate that suitable evaluations of all foresecable secondary impacts and potential alternatives had taken place"); Save Our Wetlands, Inc. v. Witherspoon, 638 F. Supp. 1158, 1165 (E.D. La. 1986) (allowing trial testimony before the district court to show that the agency considered all relevant factors in making its decision, although such evidence was "woefully lacking" in the administrative record). 
reviewable administrative record, despite the clear mandate of NEPA that the agency prepare the required record before deciding upon a particular course of conduct. Finally, if the agency knew that it could always "supplement" or "create" the adininistrative record in the reviewing court, it actually would have an incentive to prepare an madequate administrative record, and benefit by the lack of obstacles (froin its viewpoint) frequently created by informed public participation in the decisionmaking processes. ${ }^{216}$

Plaintiffs who inust build a NEPA record in court are in effect performing the task that NEPA demands of the agencies. By refusing to allow plaintiffs this opportunity, courts shield agencies from judicial oversight precisely where their own environmental review is lacking. In so doing, courts may encourage agencies to ignore their NEPA duties in the future and to address only those issues which outside groups have "proven" to a level of legal significance.

\section{The Protection of Agency Independence}

Another primciple behind the record rule is judicial respect for agency independence. This respect, in turn, reflects the judiciary's concern for constitutional separation of powers requirements. ${ }^{217}$ Courts are not to intrude upon the realin of administrative decisioninaking delegated to the executive agencies by Congress. Thus, courts have typically deferred to administrative independence in reviewing decisions to proceed with actions involving agencies' primary duties and, presumably, areas of expertise. The effect and intent of the record rule is to force an agency to coinpile a record that will justify and explain its course of action. Courts are then to uphold the agency's course as long as it appears to have some rational basis. ${ }^{218}$

Allowing the adinission of extra-record evidence to challenge an agency's NEPA record does not, however, infringe on the agency's primary autonomy. Special deference to agency independence is unwarranted in NEPA cases both because NEPA usually does not fall within the special expertise of the agency and because the ultinate decision to go through with a project is not subject to review under NEPA. ${ }^{219}$

216. Citizen Advocates for Responsible Expansion v. Dole, 770 F.2d 423, 437 n.18 (5th Cir. 1985).

217. See JAFFE, supra note 1 , at 28-33.

218. See supra notes 105-09 and accompanying text.

219. See Park County Resources Council, Inc. v. United States Dep't of Agric., 817 F.2d 609, 620 (10th Cir. 1987) ("Because ensurance of NEPA compliance is not within the special province of administrative agencies, executive and administrative autonomy and development of a factual record are ... irrelevant considerations under NEPA. ... Whether an agency needs to draft an EIS before pursuing a proposed action is unlike other administrative decisions."). 
Unlike many other statutes, 220 NEPA has not been interpreted as requiring agencies to act in the public good or to further some broad social policy. The question under NEPA is not whether an agency has acted arbitrarily im choosing a course of action, but whetlier it has prepared a comprehensive analysis of potentially significant environmental impacts. ${ }^{221}$ Under NEPA, agencies need not articulate any rationale for proceeding with a proposed action. ${ }^{222}$ While some substantive judicial review may be available under the APA's deferential "arbitrary and capricious" requirement, ${ }^{223}$ tlie agency's ultimate decision to go through witlı a project is not subject to review under NEPA.

Because of the procedural focus of NEPA cases, courts reviewing NEPA documents do not intrude into the domain of agency decisioninaking implicated by separation-of-powers concerns. Agencies retain the ultimate choice of whether, or in what manner, to proceed with the action they have proposed once they have met NEPA's procedural obligations. Thus, in examining an agency's coinpliance with NEPA procedures, a court does not directly infringe on the agency's primary functions, regardless of whether the court allows the admission of extrarecord evidence.

Because NEPA has become essentially a procedural statute, the remedy for NEPA violations also preserves agency independence. The Supreme Court cases and Cronin suggest that, in general, where an agency lias failed to consider all relevant factors or has not articulated a convincing rationale for its action, tlie proper remedy is a remand to the agency rather than an evidentiary hearing. ${ }^{224}$ An adininistrative remand shows proper deference to agency independence, allows the agency to

220. For examples of statutes granting agencies more general authority to act in the public good, see EDLEY, supra note 1, at 5 \& n.6 (identifying various statutes that delegate broad authority to agencies-for example, the Federal Communications Act, which mandates that the FCC award licenses in accordance with the "public interest, convenience and necessity").

221. This is perhaps most clearly stated in Robertson v. Methow Valley Citizens Council, 490 U.S. 332 (1989):

If the adverse environmental effects of the proposed action are adequately identified and evaluated, the agency is not constrained by NEPA from deciding that other values outweigh the environmental costs. In this case, for example, it would not have violated NEPA if the Forest Service, after eomplying with the Act's procedural prerequisites, had decided that the benefits to be derived from downhill skiing at Sandy Butte justified the issuance of a special use permit, notwithstanding the loss of 15 percent, 50 percent, or even 100 percent of the mule deer herd. Other statutes may impose substantive environmental obligations on federal agencies, but NEPA merely prohibits uninformed-rather than unwise-agency action.

Id. at 350-51 (citations and footnote omitted).

222. See supra note 140 .

223. Although the APA theoretically places some minimal requirements of rationality on an agency's ultimate decision, NEPA does not provide any additional criteria for making this determination.

224. See Cronin v. United States Dep't of Agric., 919 F.2d 439, 444 (7th Cir. 1990); see also supra notes 33 (discussing Tagg Bros.), 91 (discussing Camp), 100 (discussing Lorion) and accompanying text. 
consider the matters presented by challengers, and puts the court in a better position to determine whether agency action was arbitrary.

The fact that the appropriate remedy for a NEPA violation is a remand, however, should not preclude the admission of extra-record evidence in court. A remand without an evidentiary hearing inakes sense where a court cannot understand the justification for an agency's action or where further articulation of an agency rationale is needed. The court can make these determinations by comparing the final administrative decision to the underlying record. In contrast, however, an agency's failure to consider significant effects or alternatives under NEPA will not generally be apparent on the face of its decision. ${ }^{225}$ Thus, the court must be able to look outside the record, if necessary, to determine whether an agency's NEPA review is adequate and whether a remand is appropriate.

After determining that an agency has violated NEPA, courts typically remand the case to the agency, vacate the agency's decision, and enjoin the project or program until NEPA provisions are met. ${ }^{226}$ These decisions may create serious costs in terms of delay and expense and eventually lead to substantive changes im the final decision. ${ }^{227}$ Ultimately, however, the agency may complete the proposed project as planned. The courts only rarely use their equitable powers to order agencies to perform affirmative acts to meet NEPA requirements. ${ }^{228}$ By remanding the action to the agency to comply with NEPA procedures, the courts minimize the effect of their decisions on agency independence by giving the agency another chance to explain its reasoning and

225. See supra Section IV.A.

226. See, e.g., Sierra Club v. United States Forest Serv., 843 F.2d 1190 (9th Cir. 1988) (enjoining logging under nine challenged timber sales in national forests until an EIS was prepared); Realty Income Trust v. Eckerd, 564 F.2d 447, 457 (D.C. Cir. 1977) (noting that the "presumption is that an action proceeding in violation of NEPA should be enjoined"). The court may go so far as to set aside a project approval, however, where it appears that an injunction will be insufficient to ensure the unbiased review demanded by NEPA. See Bob Marshall Alliance v. Lujan, No. 82-015, slip op. at 12 (D. Mont. July 10, 1992) (holding that canceling oil and gas leases issued without preparation of an EIS was "the only remedy which will effectively ensure the goal envisioned by NEPA . . . by guaranteeing, to the fullest extent possible, that the defendant agencies have studied, developed and described alternatives, including the no-action alternative").

227. Delay may create an opportunity for political action. See Tom Turner, The Legal Eagles, 10 Amicus J. 25, 30 (1988) (providing an extensive, but by no means exhaustive, list of NEPA lawsuits which delayed development of sites long enough for legislative acts to preserve them from development).

228. See Fritiofson v. Alexander, 772 F.2d 1225, 1248-49 (Sth Cir. 1985) (discussing the situations in which the court should order the preparation of an EIS and declining to require such preparation in this case). However, courts faced with NEPA violations in a continuing program occasionally use their equitable discretion to order preparation of an EIS. See, e.g., Forelaws on Board v. Johnson, 743 F.2d 677, 686 (9th Cir. 1984) (declining to enjoin contracts, but ordering the agency to prepare EIS), cert. denied, 478 U.S. 1004 (1986); Seattle Audubon Soc'y v. Evans, 771 F. Supp. 1081, 1096 (W.D. Wash. 1991) (ordering the Forest Service to prepare an EIS within a year of the date of the opinion), injunction aff'd, 9S2 F.2d 297 (1991); National Wildlife Fed'n v. Benn, 491 F. Supp. 1234, 1252 (S.D.N.Y. 1980) (ordering the agency to prepare a comprehensive EIS for its ongoing program of issuing permits for ocean dumping of dredged materials). 
rationale. 229

NEPA was enacted in response to the insight that federal agencies were often too independent-that they were failing to consider fully their impacts on the world around them. In enforcing NEPA's inandate, courts may sometimes infringe on agency automony. A court, for example, may enjoin a project for which no adequate environmental review was completed (and eloquently remind the agency of its duties under NEPA). ${ }^{230}$ In the end, however, a court has no means to determine whether agencies actually have considered and weighed the environmental impacts of a project, nor a means to force them to do so. The narrowed scope of judicial review in NEPA cases thus minimizes the concern that the courts will infringe on the areas of discretion properly left to the administrative agency.

\section{Public Participation as Legitimizing Agency Decisionmaking}

The growth of public interest environmental groups and the fear of agency capture in the 1970s prompted an unprecedented increase in pub. lic participation in agency decisionmaking. By allowing public input, an agency helped legitinize its decisionmaking process in the eyes of the court. $^{231}$ The record rule is in part premised on the ideal that agency procedures will create a legitimate record upon which a higher court can fairly base its review. Indeed, by restricting their review to the record, courts may atteinpt to ensure that they will not undermine the legitimacy of agency decisions by substituting their own policy decisions for those of the agency. ${ }^{232}$

229. See JAFF, supra note 1 , at 589 (noting that remand often results in "no more than new rationalization for the same result" but suggesting that remand may benefit agency decisionmaking in the long term by inducing better investigations by the agencies).

230. See, e.g., Sierra Club v. Marsh, 872 F.2d 497, 500 (1st Cir. 1989) (declaring that an injunction could occur where an agency failed to prepare an adequate EIS, even if work on the actual project had already commenced). The Marsh court explained its rationale as follows:

NEPA is designed to influencc the decisionmaking process; its aim is to make government officials notice environmental considerations and take them into account. Thus, when a decision to which NEPA obligations attach is made without the informed environmental consideration that NEPA requires, the harm that NEPA intends to prevent has been suffered.... Moreover, to set aside the agency's action at a later date will not necessarily undo the harm. The agency as well as private parties may well have become committed to the previously chosen course of action, and new information-a new EIS-may bring about a new decision, but it is that much less likely to bring about a different one. It is far easier to influencc an initial choice than to change a mind already made up.

It is appropriate for the courts to recognize this type of injury in a NEPA case, for it refiects the very theory upon which NEPA is based-a theory aimed at presenting governmental decision-makers with relevant environmental data before they commit themselves to a course of action.

Id. at 500 (emphasis omitted). Thus, the courts may use their equitable powers to attempt, as much as possible, to prevent NEPA review from becoming an empty formality employed to justify an existing decision.

231. See supra notes $32,38-40$ and accompanying text.

232. See Stewart, supra note 1, at 1712 (noting that in theory "[a]gency decisions made after adequate consideration of all affected interests would have, in microcosm, legitimacy based on the 
The use of public participation in administrative hearings began in the 1970s as part of a backlash against a widespread fear of agency capture. ${ }^{233}$ According to soine coininentators, the whole function of administrative law changed radically in response to this backlash. ${ }^{234}$ Agencies nnoved away froin the protection of private interests and towards "the provision of a surrogate political process to ensure the fair representation of a wide range of affected interests in the process of administrative decision." 235 Many of the environmental statutes enacted during the 1970s were intended to open up the process of administrative decisioninaking by forcing agencies to respond to cominents, calling for increased public participation, authorizing citizen suits, and demanding that decision docunients and the underlying data be available for public inspection. ${ }^{236}$ By creating a pohtical forum where voices are heard, opinions are shared, and values are discussed, Congress could legitinize agency decisionmaking. ${ }^{237}$

same principle as legislation and therefore the fact that statutes cannot control agency discretion would become largely irrelevant").

233. See supra note 76; see also Cass R. Sunstein, On the Costs and Benefits of Aggressive Judicial Review of Agency Action, 1989 DukE L.J. 522, 525 ("[Legitimacy] is associated with such conventional notions as ... protection against arbitrariness and selectivity, promotion of procedural regularity, and ensurance against the twin evils of factional tyranny and self-interested representation. A particular fear of this view is that well-organized private groups ('special interests') often have disproportionate influence over administrative processes-a phenomenon that provides the basic insight behind the extensive literature on agency 'capture.' ").

234. See Stewart, supra note 1, at 1723-90 (discussing the expansion of standing rights, the expansion of participation rights before the agency, and the model of agencies as legitimized by their role as a forum where different interests may be represented). As the courts, commentators, and the public began to focus on the enormous discretion that agencies retained even under the most detailed statute, they began to search for ways to curtail and legitimize this discretion. See Rabin, supra note 1 , at 1299 (noting that judicial review in the post-New Deal era reflected a preoccupation with controlling administrative discretion).

235. Stewart, supra note 1, at 1670 . This view is often associated with Chief Judge Bazelon of the D.C. Circuit who saw the early 1970 s as a "new era" in the history of agency and court collaboration and recognized that "judicial review alone can correct only the most egregious abuses. Judicial review must operate to ensure that the administrative process itself will confine and control the exercise of discretion." Environmental Defense Fund, Inc. v. Ruckelshaus, 439 F.2d 584, 598 (D.C. Cir. 1971).

236. See, e.g., Insecticides and Environmental Pesticide Control Act, 7 U.S.C. $\$ 136$ (1988) (calling for public hearings on request); Toxic Substauces Control Act, 15 U.S.C. $\$ \S 2619,2620$ (1988) (providing for citizen suits and administrative petitions); Coastal Zone Management Act of 1972, 16 U.S.C. $\S 1457$ (1988) (mandating that underlying documents be made available to the public); Endangered Species Act of 1973, 16 U.S.C. $\$ 1540(\mathrm{~g})$ (1988) (providing for citizen suits); Surface Mining Control and Reclamation Act of 1977, 30 U.S.C. $\S 1263$ (1988) (calling for public notice and hearings); Clean Water Act, 33 U.S.C. $\$ 1365$ (1988) (providing for citizen suits); Federal Land Policy and Management Act of 1976, 43 U.S.C. $\$ 1712(\mathrm{f})$ (1988) (calling for public involvement, notice and comment procedures, and public hearings in developing land management plans).

237. Policy analysts have also proposed that statutes that provide opportunities for public participation are more likely to have their objectives attained. Paul A. Sabatier \& Daniel A. Mazmanian, Implementation of Public Policy: A Framework of Analysis, in EFFECTIVe Policy IMPLementation 13-14 (Daniel A. Mazmanian \& Paul A. Sabatier eds., 1981). This may be especially important in a statute like NEPA where the objectives are somewhat unclear, no 
NEPA was enacted in the early 1970s, before Congress focused its attention on the need to legitimize agency decisions through public input. Thus, it is perhaps not surprising that NEPA is "completely devoid of all the familiar trappings of procedural reform."238 While the text of NEPA does not demand that agencies receive a great deal of public input, the CEQ has interpreted NEPA as demanding a significant amount of public participation. ${ }^{239}$

Public comments received by agencies during the NEPA process often communicate public values directly about the issue of whether the proposed project should go forward, rather than addressing the adequacy of the EIS. ${ }^{240}$ The decision whether the proposed project should go forward despite possible significant environmental hazards, however, is exempt from judicial review under NEPA. The only question before the court is the adequacy of the EA or the EIS-generally a highly technical determination.

NEPA's open comment period, however, does little to ensure the technical competence of a NEPA document. An informal notice and comment process is not a forum where the public, with limited time and resources, can easily challenge agency technical findings. ${ }^{241}$ For exam-

particular funds are provided to implement the statute, and implementing agencies may be biased against achieving the statutory objectives and may not give the program high priority. See id. at 14.

238. See Rabin, supra note 1 , at 1287.

239. CEQ requires agencies to the greatest extent possible to "[e]ncourage and facilitate public involvement in decisions which affect the quality of the human environment." 40 C.F.R. $\$ 1500.2$ (d) (1992). The agency must include interested parties in the scoping phase, id. $\S 1501.7$, send a copy of the EIS to anyone who requests one, $i d$. $\S 1502.19$, affirmatively solicit comments from interested or affected parties, id. $\S 1503.1$, and respond to comments, id. $\$ 1503.4$.

240. One commentator has noted that general public comment is often so politically polarized and nontechnical that it is difficult for the agency to assimilate it meaningfully. See Stark Ackerman, Observations on the Transformation of the Forest Service: The Effects of the National Environmental Policy Act on U.S. Forest Service Decision Making. 20 ENVTL. L. 703, 709 (1990). Often the bulk of comments arrive on postcards provided by industry or environmental groups. See, e.g., Nickolas Facaros, Public Involvement in National Forest Planning, 4 J. ENVTL. L. \& Lirig. 1, 29 n.119 (1989) (noting that the Forest Service received over 17,500 responses to its Willamette National Forest Plan, 8584 submitted on forms distributed by timber industry groups to their employees and 3956 submitted on forms distributed by the Oregon Natural Resources Council).

241. One case study of a Bureau of Land Management NEPA process from 1985-88 analyzed the rhetoric and impact of the language used in the Bureau's EISs and the Bureau's interaction with the public. See M. Jimmie Killingsworth \& JaCQueline S. Palmer, Ecospeak: Rhetoric AND ENVIRONMENTAL Politics IN AMERICA 163-91 (1992). The authors concluded:

Part of the democratizing rhetoric of the EIS is that [the public's] responses to the draft [EIS] are included verbatim in the final EIS. But the respondents' complaints about the lack of review time, the scientific deficiencies of the study, their own lack of technical expertise, and their disadvantage in confronting an army of BLM officials indicate their tacit recognition that their voices will have little effect-rhetorical or real. They understand the contours of power as described by Jean-François Lyotard: "Access to data is, and will continue to be, the prerogative of experts of all stripes. The ruling class is and will continue to be the class of decision makers."

Id. at 186-87 (citation omitted).

Another case study of forest planning in the Willamette National Forest noted that "[a] technical understanding of planning assumptions and analyses not only poses a challenge to the 
ple, an agency may allow as few as thirty days between the publication of an EIS and its decision on a proposed action, ${ }^{242}$ giving commentators little opportumity to marshall resources and develop new data. Even the larger environmental organizations may be unable to prepare a comprehensive critique of the agency's technical conclusions during this period. 243

Where an agency's decision cannot be legitimized by a political process, the courts should turn their attention to their usual task-determining the "legality" of agency action. ${ }^{244}$ The principle of legality is invoked to "ensure that regulatory agencies comply with congressional commands."245 To best determine whether an agency has complied with NEPA's mandates-whether the agency's action is legal-the courts need to have the discretion to review evidence presented by parties challenging an agency's environmental review. They should not rely upon a comment process designed to allow input from the general public to validate an agency's technical conclusions.

Forest Service but also an obstacle to public involvement in planning decisions." Facaros, supra note 240 , at 22 .

242. 40 C.F.R. $\$ 1506.10(b)$ (1992).

243. See infra Section IV.B.2.

244. See Sunstein, supra note 233 , at $522-26$ (discussing the principles of "legality" and "legitimacy" in reviewing agency action).

The hope of the 1970s that increased public participation would democratize administrative processes seems to have been replaced by new theories of judicial review. Indeed, one commentator has noted that some courts have returned to the "oldest of administrative law values-maintaining agency constancy to congressional purpose." Merrick B. Garland, Deregulation and Judicial Review, 98 HARv. L. Rev. 505, 512 (1985). According to this commentator, this shift is based on a recognition by courts that a model focused solely on the creation of legitimacy may fail to meet the goals set out by Congress. "[M]erely ensuring the participation of all affected interests will not ensure the protection of those for whom Congress has expressed special solicitude." Id.

Professor Jaffe was one of the first scholars to reject the idea of representativeness as a safeguard against capture:

The notion of complete representativeness is an illusion, a version of nirvana. It does not exist, because it cannot. Representation means organized purpose, and at one time no more than a fraction of the potential infinity of organized purposes are in being. Policy means choice, decision, direction; and if policy is to have any stability or weight, any creative drive, it will almost inevitably be a choice of one interest over others. . . By its very nature, because [an administration] is challenged to hammer out policy against opposition, it is driven almost inevitably to seek allies and to provide cement for its alliances.

JAFE, supra note 1 , at 323 . Because he saw capture as "a necessary condition of government," Jaffe emphasized the necessity of an independent judiciary to guarantee the legality of agency action. Id. at 323.

Thus, by focusing on legality rather than legitimacy concerns, courts do not preempt democratic values. Indeed, by requiring that agency action accord with congressional mandates, courts can ensure that the "will" of the most politically responsive body is heeded. See Sidney A. Shapiro \& Robert L. Glicksman, Congress, the Supreme Court, and the Quiet Revolution in Administrative Law, 1988 DUKE L.J. 819, 864 (arguing that a checks-and-balances approach to judicial review "serves a democratic purpose, because the other branches of government often fail to ensure an agency's compliance with legislative objectives").

245. Sunstein, supra note 233 , at 522 . 


\section{E. The Threat of Sandbagging}

Concerns about sandbagging underlie much of the judicial commitment to the record rule. The record rule ensures that plaintiffs will not shirk their duty to participate in the agency decisionmaking process, only to present new evidence at trial that undermines that process. Even in the absence of a strict record rule, however, plaintiffs are already generally required to raise important objections to agency conclusions at the administrative level under the requirement of exhaustion. Courts may also exclude extra-record evidence when they believe the parties have acted in bad faith.

\section{The Impetus Behind Sandbagging Concerns}

Perhaps because NEPA has been interpreted narrowly as a procedural statute, concerns are frequently voiced about outside groups misusing the NEPA process to prevent, delay, or interfere with projects that they oppose on their merits. Thus, one discussion of a Department of Energy NEPA review concluded:

What is clear is that public comment participants did not really care about the environmental analysis. ... Their arguments concerned the merits of the rule. The NEPA challenge in the D.C. Circuit was merely one of the challenges to invalidate the rule made by those unsatisfied with the outcome of the rulemaking. ... .

In this case, NEPA's function was neither to influence agency decision making nor to publicize environmental consequences of an agency decision. Rather, NEPA placed hoops of uncertain dimensions for the agency to jump through before the agency action could be affirmed. No wonder that some agency personnel might view the NEPA process as nothing more than an artificial means of providing public interest groups with a means to challenge government action. ${ }^{246}$

It is this view of NEPA that animates sandbagging concerns. If a party's goal is merely to block a project, it has every incentive to withhold significant concerns and information. Then, after the agency has completed all its NEPA paperwork and is ready to proceed, the outside party can take the agency to court, claiming that the agency ignored or brushed aside significant information. ${ }^{247}$

246. William Funk, NEPA At Energy: An Exercise in Legal Narrative, 20 ENVTL. L. 759, 769-70 (1990).

247. See Vermont Yankee v. Natural Resources Defense Council, Inc., 435 U.S. 519 (1978). Holding that the agency's rejection of an energy conservation alternative to nuclear power development was not arbitrary and capricious, the Court stated:

[W] hile it is true that NEPA places upon an agency the obligation to consider every significant aspect of the environmental impact of a proposed action, it is still incumbent upon intervenors who wish to participate to structure their participation so that it is 


\section{The Requirement of Exhaustion of Administrative Remedies}

The requirement that plaintiffs exhaust their administrative remedies, however, greatly minimizes the threat of sandbagging. Under the judge-made doctrine of exhaustion, plaintiffs are generally precluded from raising clains in federal court if they have not first presented them to the agency. ${ }^{248}$ Like the record rule, the exhaustion doctrine promotes agency independence. Courts invoking the doctrine have expressed concern that a reviewing court "usurps the agency's function when it sets aside the adininistrative determination upon a ground not theretofore presented."249 They have concluded that "courts should not topple over administrative decisions unless the administrative body not only has erred but has erred against objection made at the time appropriate under its practice."250

The requirement of exhaustion also prevents parties from short-circuiting an established administrative process by going to court before a final administrative determination. ${ }^{251}$ Indeed, the Supreme Court has upheld the doctrine on the grounds that it is "normally desirable to let the agency develop the necessary factual background upon which decisions should be based."252 An agency must be given "a chance to discover and correct its own errors" 253 and to apply its expertise:

[S]ince agency decisions are frequently of a discretionary nature or frequently require expertise, the agency should be given the first chance to exercise that discretion or to apply that expertise.

meaningful, so that it alerts the agency to the intervenors' position and contentions. . . . [A]dministrative proceedings should not be a game or a forum to engage in unjustified obstructionism by making cryptic and obscure reference to matters that "ought to be" considered and then, after failing to do more to bring the matter to the agency's attention, seeking to have that agency determination vacated on the ground that the agency failed to consider matters "forcefully presented."

Id. at 553-54. Thus, the Supreme Court placed upon participants in the rulemaking process a duty to present their claims in a manner such that "reasonable minds" would conduct further investigation. Id. at 554.

248. See Myers v. Bethlehem Shipbuilding Corp., 303 U.S. 41, 50-51 (1938) (stating the general rule that "no one is entitled to judicial relief for a supposed or threatened injury until the prescribed administrative remedy has been exhausted"). But $c f$. KENNETH C. DAVIS, AdMinistrative LAw OF THE EIGHTIES $\S 26.1$ (Supp. 1989) ("The fundamental clearly is not that administrative remedies must be exhausted before going to a reviewing court. The fundamental is that exhaustion is usually required. Sometimes it is not."). For a more thorough treatment of exhaustion issues, see generally Marcia R. Gelpe, Exhaustion of Administrative Remedies: Lessons from Environmental Cases, 53 GEO. WASH. L. REV. 1 (1985) (reviewing the policy rationales for the doctrine and its exceptions in the context of environmental litigation and arguing for the abolition of most exceptions); Robert $\mathbf{C}$. Power, Help is Sometimes Close at Hand: The Exhaustion Problem and the Ripeness Solution, 1987 U. ILL. L. REV. 547 (reviewing the exhaustion doctrine and proposing that courts reformulate the doctrine to follow the ripeness doctrine).

249. Unemployment Compensation Comm'n v. Aragon, 329 U.S. 143, 155 (1946).

250. United States v. L.A. Tucker Truck Lines, 344 U.S. 33, 37 (1952).

251. See SchWARTZ, supra note $7, \S 8.37$ (discussing exhaustion and jurisdiction).

252. McKart v. United States, 395 U.S. 185, 194 (1969).

253. Id. at 195. 
And of course it is generally more efficient for the administrative process to go forward without interruption than it is to permit the parties to seek aid from the courts at various intermediate stages. ${ }^{254}$

Application of the exhaustion doctrine is a matter of judicial discretion. ${ }^{25 s}$ Typically, parties must make use of whatever administrative appeals are available before seeking resolution of their disputes in the court. ${ }^{256}$ Where an agency has established no procedures for appeal, however, plaintiffs may be able to seek judicial review after pursuing all other available procedures. ${ }^{257}$ In addition, if the delay involved in exhausting administrative avenues is unreasonable $e^{258}$ or if the plaintiff can show irreparable injury, ${ }^{259}$ courts may intervene prior to exhaustion. ${ }^{260}$

Exhaustion must be tailored to "an understanding of its purposes and of the particular administrative scheme involved."261 Thus, some

\section{Id. at 194.}

255. See 4 Kenneth C. Davis, Administrative Law Treatise $\S 26: 7$ (2d ed. 1983) ("[T]he reviewing court has power to exercise discretion in the light of the circumstances and the court's ideas as to what justice requires."); JAFFE, supra note 1, at 424-26 (discussing the rationale for the rule of exhaustion and its history of largely discretionary application).

256. Professor Davis has argued that intra-agency appeals should not be a prerequisite for judicial review. See DAVIS, supra note 255, $\$ 26: 12$ (basing his argument on the Administrative Procedure Act, 5 U.S.C. $\$ 704$ (1988), which provides that "[e]xcept as otherwise expressly required by statute, agency action otherwise final is final for the purposes of this section whether or not therc has been presented or determined any application ... for an appeal to superior agency authority").

257. See, e.g., Portland Audubon Soc'y v. Lujan, 712 F. Supp. 1456, 1460-62, 1483 (D. Or. 1989) (holding that judicial review was not barred when plaintiff's appeal to the Interior Board of Land was never taken up by the Board), aff'd in part, rev'd in part on other grounds, 884 F.2d 1233 (9th Cir. 1989), cert. denied, 494 U.S. 1026 (1990); City of Irving v. Federal Aviation Admin., 539 F. Supp. 17, 34 (N.D. Tex. 1981) (upholding plaintiffs' right to judicial review on the grounds that the Federal Aviation Administration had provided no administrative remedies for challenging its failure to prepare an EIS).

NEPA does not require that agencies have any form of appeal process. If such a process is provided for in agency regulations, however, a party may be able to appeal within the administrative process if he or she is dissatisfied with the agency's response to their comments in the final EIS. Even at the administrative appeal stage, though, a party may be limited to those issues presented during the initial planning process. See, e.g., 43 C.F.R. $\S 1610.5-2$ (a) (1992) (Bureau of Land Management protest procedures).

258. See Sierra Club v. Lyng, 694 F. Supp. 1256, $1258-59$ (E.D. Tex. 1988) (holding that while "[e]xcessive administrative delay can be an exception to the exhaustion requirement," an estimated delay of eight to fifteen months until administrative appeal was settled with possible adverse impacts on 5000 out of 460,000 acres of national forest did not warrant judicial intervention); Utah Int'l, Inc. v. Andrus, 488 F. Supp. 962, 974-75 (D. Utah 1979) (holding that a nine-year delay caused in part by ongoing NEPA review at the agency level did not excuse a coal leaseholder from exhausting its administrative remedies).

259. See, e.g., Southeast Alaska Conservation Council, Inc. v. Watson, 697 F.2d 1305, 1309 (9th Cir. 1983); Stein v. Barton, 740 F. Supp. 743, 747 (D. Alaska 1990).

260. Some courts may refuse to apply the exhaustion doctrine in cases where the chances of obtaining adequate relief through administrative remedies are minimal. See Park County Resource Council, Inc. v. United States Dep't of Agric., 817 F.2d 609, 616 (10th Cir. 1987).

261. McKart v. United States, 395 U.S. 185, 193 (1969). 
courts have refused to impose the exhaustion requirement in NEPA cases for many of the same reasons that the NEPA exception to the record rule has been developed-that it requires plaintiffs to jump over too many procedural hurdles and may inhibit their ability to prove that the agency was derelict in its consideration of relevant factors. ${ }^{262}$ Potential plaintiffs, however, still face the risk that a court may demand exhaustion, especially if the court does not feel that plaintiffs made a good faith effort to raise important issues before agencies. This exhaustion requirement reduces the risks of sandbagging by plaintiffs and helps ensure that most issues are raised before the administrative agencies.

When the court combines the requirement of exhaustion with a strict application of the record rule, plaintiffs' ability to challenge an EIS is severely restricted. Without judicial review of extra-record evidence, potential plaintiffs must not only exhaust administrative remedies, they must also present enough evidence to the agency prior to its final decision to convince a court that an agency action is significant or will have a specific impact on the environment. While plaintiffs may raise such issues in their briefs, without further documentation the court is unlikely to find that the agency acted arbitrarily. ${ }^{263}$

Even without the requirement of exhaustion, however, sandbagging concerns should not be overemphasized. Since public interest groups often work very closely with agencies over the long-term, it is to their advantage to be perceived as genuine in their efforts to promote environmental reform. ${ }^{264}$ In addition, litigation is expensive. Interest groups

262. See, e.g., Southeast Alaska Conservation Council, 697 F.2d at 1309 (exhaustion not required where agency failed to prepare an EIS and an immediate decision was necessary to determine the appropriateness of a permanent injunction and the need for an EIS); Sierra Club v. ICC, [1978] 8 Envtl. L. Rep. (Envtl. L. Inst.) 20,265, 20,267 (D.C. Cir. Feb. 21, 1978) (stating that the courts shall apply the exhaustion doctrine flexibly with regard to whether a compelling governmental interest would justify the forfeiture of judicial review); California v. Bergland, 483 F. Supp. 465,473 n.5 (E.D. Cal. 1980) (noting that "[l]aches and failure to exhaust administrative remedies are disfavored doctrines in NEPA cases"), aff'd in part, rev'd in part sub nom. California v. Block, 690 F.2d 753 (9th Cir. 1982); Natural Resources Defense Council, Inc. v. Morton, 388 F. Supp. 829, 835 (D.D.C. 1974) (holding that a challenge to Bureau of Land Management's Grazing Program for failure to file an EIS was not precluded by the exhaustion doctrine where the agency provided no hearing procedure with respect to the program), aff'd, 527 F.2d 1386 (D.C. Cir. 1976), cert. denied, 427 U.S. 913 (1976). See generally Paul D. Friedland, Comment, The Exhaustion Doctrine and NEPA Claims, 79 Colum. L. REV. 385 (1979) (arguing that, in deciding whether to apply the exhaustion doctrine in the NEPA context, courts should balance a plaintiff's participation in the administrative procedures against an agency's compliance with NEPA-mandated procedures).

263. Proving that an agency action is arbitrary and capricious can be extremely difficult:

In the thousands of federal court decisions annually reviewing federal administrative action, only a comparative handful invalidate agency action on this ground. Litigants attempting to persuade a reviewing court that the balance struck by an agency among relevant factors is "arbitrary and capricious" must be prepared to persuade the court that the agency's decision has no rational basis whatsoever. Given the artfulness of agency opinion writers, the skills of government lawyers, and the plausibility of agency claims of "expertise," this is a difficult burden to carry.

BREYER \& STEWART, supra note 44, at 289 (footnote omitted).

264. For example, the Environmental Defense Fund, whose first campaign was a series of 
cannot afford to bring to court every EA or EIS on which they comment. Where interest groups can convince agencies that their position is correct without litigation and can develop a more cooperative relationship with the agencies, or at least certain factions within the agencies, the groups can use their financial resources more efficiently. ${ }^{265}$

\section{Imposing a Good Faith Requirement on Plaintiffs}

Finally, concerns about sandbagging could be addressed by imposition of a good faith standard. The First Circuit has outlined an exception to the record rule where the agency knew about "some important matter that the EIS ignored (and which the commenting parties did not know about and could not have pointed out . . .)."266 Instead of requiring plaintiffs to show bad faith, courts could employ similar logic to determine whether plaintiffs have met a good faith standard: did plaintiffs know about relevant information that the agency did not know about and could not have discovered and in bad faith fail to point it out to the agency during the administrative process? Only if these conditions are met should courts exclude plaintiffs' extra-record evidence. Placing the difficult burden of proving bad faith on the agency is appropriate in NEPA cases, where the agency is arguing that its failure to examine potentially significant environmental impacts or data should not be subject to review.

\section{IV}

\section{BALANCING THE BURDENS ON ENVIRONMENTAL PlainTiffs}

Even courts that do not address the kind of bad faith raised by sandbagging concerns have sought to define the reasonableness of an agency's conclusions, not by admitting extra-record evidence, but by examining objections made during the administrative process. Clearly, an agency cannot scrutinize every conceivably possible impact of, and alternative to, its proposed action. ${ }^{267}$ Some courts have reasoned that this practical limitation necessarily places a burden on NEPA plaintiffs to raise their concerns during the administrative phase of the NEPA pro-

lawsuits to force the EPA to ban DDT, has developed a more cooperative relationship with industry and the executive branch in the recent past. See Rose Gutfeld, Environmental Group Doesn't Always Lick 'Em; It Can Join 'Em and Succeed, WAll ST. J., Aug. 20, 1992, at Bl.

265. For a discussion of the apparently fruitful interaction between one public interest group, Northwest Coalition for Alternatives to Pesticides, and the Forest Service, see generally O'Brien, supra note 183.

266. Valley Citizens for a Safe Env't v. Aldridge, 886 F.2d 458, 460 (1st Cir. 1989).

267. See Vermont Yankee Nuclear Power Corp. v. Natural Resources Defense Council, Inc., 435 U.S. 519, 551 (1978) (asserting that a statement of alternatives "cannot be found wanting simply because the agency failed to include every alternative device and thought conceivable by the mind of man"). 
cess. The First Circuit has noted that "one cannot ordinarily expect an agency to do inore than make reasonable efforts to gather relevant information and then to evaluate that information in light of the comments interested parties have inade."268 This approach thus defines an agency's NEPA duties with reference to the degree of participation by commenting parties. ${ }^{269}$

Requiring potential plaintiffs to raise significant environmental effects or alternatives during the administrative process, however, is a inisperception of the directives of NEPA. Such a requirement creates a participatory obligation for potential plaintiffs where NEPA imposes none. County of Suffolk v. Secretary of Interior, for example, demonstrates a court's reluctance to force plaintiffs to take upon themselves the agency's duty to prepare an adequate EIS. In that case, the court noted that to force plaintiffs to prove alleged impacts before the agency "would in effect shift the burden of insuring the adequacy of the EIS to environmental challengers, even though the primary and nondelegable responsibility for providing such analysis hes with the agency."270

This Part will define the roles that commenting parties and agencies

268. Valley Citizens, 886 F.2d at 460 .

269. Other cases that appear to take this approach include Kentucky ex rel. Beshear v. Alexander, 655 F.2d 714, 718 (6th Cir. 1981) (noting that "a significant factor in whether the specificity of an agency's examination of alternatives is an abuse of discretion is how meaningful was the participation in agency proceedings by intervenors') and Havasupai Tribe v. United States, 752 F. Supp. 1471 (D. Ariz. 1990), aff'd, 943 F.2d 32 (9th Cir. 1991), cert. denied, 112 S. Ct. 1559 (1992). In Havasupai Tribe, the court restricted review to the administrative record and stated that whilc the agency "repeatedly sought clarification of plaintiff's comments," the Havasupai "declined to participate or structure their participation in a meaningful manner during the administrative action. Accordingly, the plaintiffs cannot complain that the agency's consideration of their religious concerns [in an EIS] was inadequate." Id. at 1500; see also supra note 247.

270. County of Suffolk v. Secretary of Interior, 562 F.2d 1368, 1385 (2d Cir. 1977), cert. denied, 434 U.S. 1064 (1978). Early cases interpreting NEPA were generally insistent that plaintiffs not be forced to prove, before litigation began, the environmental impacts that they were alleging that the agency had been derelict in ignoring:

Were we to agree with the district court that a NEPA plaintiff's standing depends on "proof" that the challenged federal project will have particular environmental effects, we would in essence be requiring that the plaintiff conduct the same environmental investigation that he secks in his suit to compel the agency to undertake. Compliance with NEPA is a primary duty of every federal agency; fulfillment of this vital responsibility should not depend on the vigilance and limited resources of environmental plaintiffs. It is the federal agency, not environmental action groups or local government, which is required by NEPA to produce an EIS.

City of Davis v. Coleman, 521 F.2d 661, 670-71 (9th Cir. 1975) (emphasis and footnote omitted); see also Sierra Club v. Mason, 351 F. Supp. 419 (D. Conn. 1972) (employing only minimal standing requirements because "[t]o oblige [a plaintif] to allege more than a generalized, non-frivolous threat to the environment in which he lives, works or plays might, in some cases, require him to state what has not yet been determined but what may be detailed in the environmental impact statement he wants prepared").

Both Coleman and Mason raise these concerns in the context of an examination of the requirements for standing in NEPA cases. See infra text accompanying notes 298-317. The discussions in the cases, however, are also relevant to this more basic discussion about the relative duties of agencies and potential plaintiffs in the NEPA context. 
should and do play in the NEPA process. It concludes that because NEPA places duties only on federal agencies, the agency's duty to gather relevant information should not vary according to the degree of outsider participation in the administrative process. Outside groups do not have the resources to step into the role of the agency and build a coinprehensive record of significant environmental impacts at every adininistrative NEPA proceeding. They are already required to inake a coinpelling case in court that agency conclusions are unreasonable. The record rule greatly impedes their ability to nake this case and thus undercuts the protection that judicial review provides against inadequate NEPA review.

\section{A. The Private Law Model}

In defining the role of outside groups, it is iniportant to distinguish the function of public interest lawsuits froin private suits. In NEPA cases, agency decisions will often have diffuse and wide-ranging inıpacts and will generally be challenged only by public interest groups. ${ }^{271}$ In contrast, in private suits, witl a limited nuniber of clearly defined actors who are likely to liave highly individual responses to an adninistrative action, review of extra-record evidence may be less appropriate. For example, Doraiswamy v. Secretary of Labor ${ }^{272}$ is widely cited in support of a strict record rule. ${ }^{273}$ In that case, the Secretary of Labor denied two work permits to alien petitioners based on his finding that American workers were available for the positions that the aliens wislied to fill. ${ }^{274}$ Similarly, in Camp v. Pitts, ${ }^{275}$ the Comptroller of the Currency refused to issue a certificate authorizing the organization of a private bank. ${ }^{276}$

In such cases, application of the record rule makes sense. In these situations, where the agency took action only at the plaintiff's request, ${ }^{277}$ it is unlikely that affected parties will sleep on their rights or be unaware of the impacts of the agency's decision. In addition, in private actions seeking personal rehef, there is no concern that the inipacts of the actions will be so diffuse that appropriate resources cannot be niarshalled at the adninistrative stages. Plaintiffs in both cases also had a chance to seek an administrative appeal. ${ }^{278}$ Thus, they were on fair notice that their

271. See CEQ 20TH ANNUAL REPORT, supra note 136, app. B at 393.

272. 555 F.2d 832 (D.C. Cir. 1976).

273. In refusing to allow petitioners to introduce new evidence about the availability of substitute labor, the court found that "the legality and reasonableness of the agency's action ... [must] be determined solely on the basis upon which the action was administratively projected." Id. at 840 (footnote omitted).

274. Id. at 835-38.

275. 411 U.S. 138 (1973).

276. Id. at $138-39$.

277. See Camp, 411 U.S. at 138; Doraiswamy, 555 F.2d at 835-36.

278. In Doraiswamy, the Secretary granted reconsideration of one plaintiff's petition after it was denied, and had considered the other plaintiff's application for certification three times. $555 \mathrm{~F} .2 \mathrm{~d}$ at 
claims were in jeopardy.

In such cases of purely private concern, petitioners properly bear the burden of convincing the agency of the validity of their claims. ${ }^{279}$ At least in cases where an opportunity for appeal is allowed, limiting judicial review to the administrative record may often be appropriate.

\section{B. NEPA Litigation and the Role of Public Interest Groups in the Development of Environmental Law}

When considering the burdens that should be placed on NEPA plaintiffs during the administrative process, it is important to recognize that the vast inajority of NEPA plaintiffs are not individual actors but citizen groups and environmental public interest organizations. ${ }^{280}$ Pubhic interest groups have in large ineasure shaped and developed environmental law. Beginning with the enactment of NEPA, Congress and state legislatures began a new era of environmental regnlation of public lands, waters, and coastal zones, protection of endangered species and wilderness areas, and restrictions on the use of insecticides, hazardous wastes, and other toxins. ${ }^{281}$ These laws were enforced by the executive branches primarily through administrative agency action aganist violators. In the courts, however, nongovernmental actors have played an enormous role in demanding that both private parties and governinental agencies comply with legislative inandates.

\section{The Growth of Environmental Public Interest Groups as Agency Watchdogs}

The role of public interest groups as agency "watclidogs" lias been made possible only through a coinbination of developinents. The first is the growth of the groups themselves. Froin tlie founding of the Sierra Club in 1892 to Earth Day 1970, a growing constituency that was broadly interested in environinental or conservation inatters liad developed. $^{282}$ By 1971, three inajor environmental litigating organizations-

835, 837. In Camp, after the original refusal, the Comptroller granted reconsideration and conducted a field examination to obtain new evidence, but denied the certificate. 411 U.S. at 139.

Allowing at least one level of administrative appeal where new evidence may be produced would appear to increase, rather than decrease, the overall efficiency of the administrative process. In this way, petitioners are not forced to develop their strongest possible case in the initial petition, which could cause needless and expensive "overkill."

279. As in Carlo Bianchi, discussed supra at notes 59-63 and aceompanying text, the court in Doraiswamy was also concerned with the values and assumptions behind the underlying statute. In applying the record rule, the district court first looked to the language of the Immigration and Nationality Act and concluded that once the Secretary determined that a potential pool of workers existed in the market, the burden shifted to the aliens to prove that no qualified workers were available for that job. Doraiswamy, 555 F.2d at 839 .

280. See supra note 271.

281. See supra note 236.

282. See Victor B. Scheffer, The Shaping of Environmentalism in America 3-15 (1991) (discussing the roots of environmentalism). 
the Environmental Defense Fund, the Natural Resources Defense Council, and the Sierra Club Legal Defense Fund-were in place. ${ }^{283}$ By the end of the Reagan and Bush years, they were firmly established, with multi-million dollar budgets and tens of thousands of members. ${ }^{284}$

Often to their own surprise, these groups found that, rather than fighting industrial polluters directly, they were devoting the bulk of their resources to challenging government actions with potentially destructive environmental effects or trying to goad agencies into complying with congressional mandates. ${ }^{285}$ Congress soon recognized the important role played by public interest groups by mcorporatimg citizen suit provisions in statutes such as the Endangered Species Act and the Clean Water Act. ${ }^{286}$

The environmental public interest groups have come to play an important structural role in the development of federal and state environmental policy. ${ }^{287}$ They have laid claim to the often diffuse public rights created by the environmental regulations of the last several decades. ${ }^{288}$

283. Id. at 138-39 (The Environmental Defense Fund was founded in 1967, the Natural Resources Defense Council in 1970, and the Sierra Club Legal Defense Fund in 1971.).

284. See Environmental Defense Fund, 25Th ANNIVersary Report 1967-1992, at 2 (1992) (stating that for fiscal year 1991-92, the Fund had annual support and revenue of $\$ 20.2$ million, a staff of over 140, and over 200,000 members); NATURAL ResourCES DEFENSE CouNCIL, TWENTY YEARS DEFENDING THE ENVIRONMENT 16 (1990) (membership of 125,000 and staff of 150 in 1990); Natural Resources Defense Council, 1992 ANnual Report 8 (1993) (budget of over \$17 million for fiscal year 1992); SIERRA Club Legal Defense Fund, 1991-1992 ANNUAL REPORT 9 (150,000 supporters and a budget of over $\$ 10$ million in 1992), reprinted in IN BRIEF (Sierra Club Legal Defense Fund, San Francisco, Cal.), Winter 1993.

285. One study of environmental litigation in the 1970s found that the most common type of environmental litigation in the district courts was that of a public interest group suing the government. See Lettie M. Wenner, The ENvironmental DeCAde IN Court $39-41$ (1982). The second most common was that of industry suing the government, the third most common was that of the government suing industry, and the least common was intergovernmental suits. Id. at 4042. The differences in frequency among the three most common types of litigation grew narrower towards the end of the decade. Id. at 42-44; see also 137 CONG. REC. E3185 (daily ed. Sept. 30, 1991) (statement of Rep. Boxer, reading into record the earlier speech of Fredric P. Sutherland, former president of Sierra Club Legal Defense Fund, asserting that "the Government is all too often the environment's worst enemy").

286. See Endangered Species Act of 1973, 16 U.S.C. $\S 1540(\mathrm{~g})$ (1988) (providing for citizen suits); Clean Water Act, 33 U.S.C. § 1365 (1988) (same).

287. See George Hoberg, Pluralism by Design: Environmental Poljcy and the American Regulatory State 53-56 (1992) (discussing the "increasing infiuence" of environmental groups in agency regulation); ROSENBAUM, supra note 134, at 39 (discussing the role of environmental interest groups in policy-making); WENNER, supra note 285, at 45 (claiming that NEPA lawsuits initiated by the Natural Resources Defense Council changed the administrative policies of the Departments of Interior and Agriculture); Henry C. Kenski, The President, Congress, and Interest Groups: Environmental Policy in the 97th Congress, in PUBLIC POLICY AND THE NATURAL ENVironment 77 (Helen M. Ingram \& R. Kenneth Godwin eds., 1985) (analyzing the conflict between environmental groups, Congress, and the Reagan administration over environmental policy); Turner, supra note 227 , at 25 (describing the history of environmental litigation since 1969).

288. See SCHEFFER, supra note 282, at 132-40 (discussing the growth of public interest environmental litigation organizations and concluding that "[h]ad not the environmental revolution 
In addition, they are almost always the only "citizens" with the resources and expertise to challenge agency action and to overcome the immense hurdle of deferential judicial review. ${ }^{289}$

\section{The Financial Limitations of Public Interest Groups}

Despite the role that public interest groups can play in environmental law, financial considerations clearly limit their impact. Most state and local organizations liave very modest budgets. One recent survey of 248 nongovernmental environmental and conservation organizations across the country determined that the median annual budget was only $\$ 360,000{ }^{290}$ Most liad fewer than five full-time paid staff. ${ }^{291}$ Even multi-million dollar organizations are affected by severe financial constraints. The expense of litigation forces environmental groups to choose their lawsuits carefully, based on the likelihood of creating important favorable legal precedent and effecting real clianges in government policy. ${ }^{292}$

won for ordinary Americans new standing im the courts, it would have been little more than a brief discursion in history").

289. The general public's lack of techrical knowledge has long been recognized as a severe obstacle to effective participation in agency review processes. For example, Professor Joseph Sax noted in 1973 that NEPA's mandate to include the public often failed because "ordinary householders have no expertise, little money, and even less knowledge as to where to find experts or even the literature upon which to raise appropriate questions." Joseph L. Sax, The (Unhappy) Truth About NEPA, 26 OKLA. L. REV. 239, 246 (1973). He concluded that "[w]e have accepted the principle of public participation, but we have no established mechanisms to assure that members of the public have the professional resources to operate as knowledgeable and informed participants." Id.

This condition has improved little since the early 1970 s, as Judge Patricia M. Wald of the D.C. Circuit recently observed:

[O]rdinary citizens rarely if ever have the financial resources and know-how to undertake a major challenge to an official government action. Environmental litigation is timeconsuming, the statutes are complex, and it often takes several years before a court challenge is decided. Fortunately, $m$ addition to citizens, there are powerful environmental organizations that have the skill, expertise, and money to present environmental challenges in court.

Patricia M. Wald, The Role of the Judiciary in Environmental Protection, 19 B.C. ENVTL. AFF. L. REV. 519, 526 (1992) (footnote omitted). Judge Wald notes that the "expertise of these environmental organizations assures the court that it is receiving all relevant data" and concludes that without it, "the court often would be putty in the hands of the government." Id. at 527.

290. Donald Snow, Inside the Environmental Movement 52 (1992).

291. Id. at 53 .

292. See ROSENBAUM, supra note 134, at 71-72 (noting that several national legal organizations "specialize almost exclusively in initiating litigation or intervening in administrative procedures of federal and state governments for the purpose of establishing important legal precedents or creating significant legal issues"); TAYLOR, supra note 198, at 388 n.14 (noting that the major litigation organizations think systematically about their overall legal strategies in light of their limited financial resources).

Furthermore, any new information that the major organizations need to gather for an administrative or judicial appeal can be expensive to obtain. Highly-trained experts often inust visit the relevant sites and prepare affidavits or reports. Telephone Interview with Johanna $\mathrm{H}$. Wald, Attorney, Natural Resources Defense Council, Inc. (May 21, 1993). 
A stringent record rule would exacerbate these financial difficulties. Since under the record rule extra evidence cannot be introduced to the courts, it becomes imperative for interest groups to ensure that the administrative record is essentially complete, with all major concerns coming to light. Sucl coinpleteness requires finances and know-how. The larger interest groups have acquired these resources to some extent. However, even these multi-million dollar organizations are not capable of monitoring every case in which the federal government prepares-or fails to prepare-a NEPA document. ${ }^{293}$

As a result, the inomitoring and contesting of these agency activities is largely left to the smaller interest groups. ${ }^{294}$ However, while monitoring government agencies is an important goal for most of the environmental organizations, the inajority are seldom or never involved in hitigation. ${ }^{295}$ As a result, nost of the small groups involved in watchdog activities are unlikely to have experience in building the kind of comprehensive record necessary for a successful legal challenge. ${ }^{296}$ Thus, these agencies inay fail to put forward a complete record.

The record rule creates even inore obstacles for public interest groups when agencies do not offer, or greatly restrict, internal appeals processes. In such cases, environinental interest groups are forced to address every case at the imitial administrative level-once a decision has been inade, no more public input can be accepted or considered. ${ }^{297}$

293. For example, from 1969-78, about 10,000 EISs and 20,000 to 40,000 EAs were prepared. See TAYLOR, supra note 198, at 351. This trend has continued so that, in 1990, federal agencies prepared 477 EISs. See CEQ TWENTIETH ANNUAL REPORT, supra note 136, at 238.

294. See generally Philip Shabecoff, A Fierce Green Fire: The American ENVIRONMENTAL MOVEMENT 231-50 (1993). There are an estimated 25 million people who are members of environmental organizations, most of them local groups. Id. at 233. Shabecoff concludes that "[w]hile the legislative and legal battles won by the big national groups provided many of the tools used by grass-roots organizations, the activities of the national groups have little immediate relevance to the local organizations fighting their acre-by-acre, dump-by-dump battles." Id.; see also Valerie J. Gunter \& Barbara Finlay, Influences on Group Participation in Environmental Conficts, 53 RuRaL Soc. 498, 498, 501 (1988) (presenting results of a study of 38 environmental conflicts in Texas from 1977.83 that found that grassroots organizations participated in $55 \%$ of the disputes and local chapters of national environmental organizations in $34 \%$, while national environmental organizations were directly involved in only $26 \%$ of the confiicts).

295. SNOw, supra note 290 , at 57.

296. In her study of environmental litigation in the $1970 \mathrm{~s}$, Wenner noted that "[t]here was a significant difference in the percentage of victories achieved, depending on whether the plaintiff was a national organization, an ad hoc organization, or had no organizational strength." WENNER, supra note 285 , at 59 . The national organizations achieved the highest success rates, although ad hoc organizations brought almost twice as many cases. Id. at 58.

297. The earlier outside groups are required to provide input, the greater the burdens on those groups become. For example, Taylor notes that effective participation in the scoping process, by which agencies initially identify the major issues to be addressed in the EIS, requires that outside groups be both farsighted and technically proficient:

Scoping provides a new opportunity for outsiders, but it also requires a greater effort, in some cases nearly as great as that for EIS lawsuits. It rewards technically well-armed participants who have a relatively long time perspective. In presenting a specific proposal, a draft EIS makes vague issues more concrete and provides a stimulus to wider public 
Furthermore, if all public input is predecisional and the record rule is strictly enforced, the public loses its ability to marshall resources to fight against decisions it considers most crucial. Sucli an approach could reduce public interest group input to the poimt where it no longer has much power to influence agency decisions.

\section{Standing}

Standing requirements can also increase the burdens on environmental organizations. Standing ensures that parties have a sufficient interest in the controversy to litigate adequately ${ }^{298}$ and to make a "case" amenable to judicial determmation. ${ }^{299}$ As NEPA has no independent standmg provisions, standmg is governed by the APA, which provides: "A person suffering legal wrong because of agency action, or adversely affected or aggrieved by agency action within the meaning of a relevant statute, is entitled to judicial review thereof." 300 The question in standing 'is not whether an agency violated 'the law,' but whether it has violated any duty owed the plaintiff.",301

discussion, thus aiding the environmentalists' political campaign. But how many environmental groups will choose to become involved in scoping meetings two or three years before any specific action is proposed? Not only must these groups see the connection between the scoping decisions and possible fights several years later, but also these primarily volunteer organizations must be able to resist the pull of more immediate 'crises' that can soak up all their energies.

TAYLOR, supra note 198 , at 279.

298. See Sierra Club v. Morton, 405 U.S. 727, 732 (1972) ("[T]he question of standing depends upon whether the party has alleged such a 'personal stake in the outcome of the controversy' as to ensure that 'the dispute sought to be adjudicated' will be presented in an adversary context . . .." (citations omitted)).

299. See Lujan v. Defenders of Wildlife, 112 S. Ct. 2130, 2136 (1992).

300. 5 U.S.C. $\$ 702$ (1988).

301. Stewart, supra note 1 , at $1736-37$ (footnotes omitted). In the public law context, the question of agency duties toward potential plaintiffs is less clear than in the traditional private law model. Professor Sunstein has noted that in the shift from a private-law model to a public-law model,

the right-duty relationship between the government and any particular legal complainant is not crisp and bilateral. ... The failure to consider a relevant factor, or the consideration of an irrelevant factor, might well be thought of as a breach of a legal duty owed by the government to the complainant. But the inquiry into consideration of relevant factors does not have a clear parallel in private-law actions.

Cass R. Sunstein, Standing and the Privatization of Public Law, 88 Colum. L. REv. 1432, 1446 (1988).

Professor William Fletcher has argued that anyone who can make a colorable claim of injury should be allowed standing in NEPA cases. See William A. Fletcher, The Structure of Standing, 98 YALE L.J. 221, 259 (1988). He explains his position in a manner that draws many parallels with the question of burden of proof for environmental plaintiffs:

[Courts should apply a low standing threshold in NEPA cases] because of the nature of the remedy plaintiff is seeking. She wishes to compel an investigation and the preparation of a report that spells out in detail what she has claimed will be the likely environmental consequences of the proposed federal action. To require a greater showing by plaintiff of actual effect would be to require, as a condition of bringing suit, that plaintiff show much of what she claims should be investigated.

Id. This view has gained some approval from recent courts, although it has not been widely 
Limitations on standing determine the scope of a lawsuit that a party can bring. In 1972, for example, Sierra Club v. Morton ${ }^{302}$ paved the way for environmental groups whose members could show injury to their aesthetic or environmental well-being to bring their claims before the courts. ${ }^{303}$ For at least a decade, standimg was nearly a dead issue for environmental plaintiffs. ${ }^{304}$ The Supreme Court's recent decision in Lujan v. National Wildlife Federation, ${ }^{305}$ however, has once again stressed the importance of standing in determining environinental plaintiffs' access to the courts. ${ }^{306}$

In this case, the respondent environmental group challenged the Bureau of Land Management's so-called "land withdrawal review program." 307 Under this "program," the Bureau reclassifies certain public lands as available for minimg activities. ${ }^{308}$ To establish standing for its case, respondent sought to use two affidavits provided by its inembers. ${ }^{309}$ These affidavits concerned allegations of particular harm caused to individual inembers by specific Bureau decisions. ${ }^{310}$ The Court, however, deemed these affidavits insufficient to grant respondent standing to challenge the entire Bureau "program." 311 The Court held that challengers cannot gain standing by seeking "wholesale improvement" of broad national policies and regulations. ${ }^{312}$ Rather, they must challenge "concrete" actions with site-specific impacts. ${ }^{313}$

The Supreine Court recognized that this approach would be "understandingly frustrating to an [environinental] organization ... which has as its objective across-the-board protection of our Nation's wildlife and

accepted. See Idaho Conservation League v. Mumma, 956 F.2d 1508, 1513 n.10 (9th Cir. 1992) (citing Fletcher, but adhering to a more traditional mode of standing analysis); Overseas Shipholding Group, Inc. v. Skinner, 767 F. Supp. 287, 293 (D.D.C. 1991) (citing Fletcher to support the conclusion that "[f]orcing a plaintiff to demonstrate 'proof' of the alleged harm at the summary judgment stage of a NEPA case defies the statute's overriding informational and investigative purposes").

302. 405 U.S. 727 (1972).

303. Id. at 734-35; see also RoSENBAUM, supra note 134, at 47 (discussing standing for environmental groups in the 1970s).

304. See Jerry L. Mashaw, "Rights" in the Federal Administrative State, 92 Yale L.J. 1129, 1137 (1983) (noting that for a time in the 1970s, the requirement of proving standing "seemed destined for oblivion").

305. 497 U.S. 871 (1990).

306. Id. at 879. Two years after National Wildife Federation, the Court dealt another blow to standing in environmental cases in Lujan v. Defenders of Wildlife, 112 S. Ct. 2130 (1992), which called into question Congress' power to grant standing through citizen suit provisions to someone having only "a generally available grievance about government." Id. at 2142-43.

307. National Wildlife Fed'n, 497 U.S. at 875 . It is the respondent who has categorized the Bureau's actions here as part of a general "program."

308. Id. at 879 .

309. Id. at $880-81$.

310. Id. at $892-93$.

311. Id.

312. Id. at 891 .

313. Id. 
the streams and forests that support it."314 By forcing plaintiffs to address issues on a case-by-case basis, National Wildlife Federation prevents environmental groups from making broad attacks on higher-level agency decisions. ${ }^{315}$ Instead, these groups are forced to undertake a series of challenges to individual EAs and EISs-addressing each project's individual and cnmulative impacts. ${ }^{316}$ They also must find a party who will be sufficiently negatively impacted by each decision to meet the criteria for standing. A restrictive apphication of the record rule would, in addition, require that plaintiffs essentially prove each case at the adinimistrative level. Combined with the record rule, stringent standing requirements can exhaust the resources of environmental groups even more quickly. ${ }^{317}$

\section{The Burden of Proof}

Even if NEPA plaintiffs are able to satisfy the standing requirements, they face an additional hurdle once they arrive in court: the burden of proof. Different burdens apply based on whether the allegation concerns the failure to prepare an EIS or the inadequacy of an existing EIS. When an agency fails to complete an EIS, courts tend to require that the plaintiff allege "facts which, if trne, show that the proposed project may significantly degrade some human environmental factor."318 Although not a highly restrictive standard, ${ }^{319}$ this can prove burdensome

314. Id. at 894 .

315. See also Lujan v. Defenders of Wildlife, 112 S. Ct. 2130, 2140 (1992) (stating that claims attacking general governmental programs-rather than specific decisions of government agencieswould rarely be appropriate for judicial resolution). Karin Sheldon, an attorney for the National Wildlife Federation, notes that National Wildlife Federation "may restrict opportunities for programmatic lawsuits" and advises that "[t]o avoid the exhausting exercise of fighting individual fires across the public landscape, environmental lawyers should refocus their litigation lens away from the programmatic and toward suits of a more modest scope." Karin Sheldon, NWF v. Lujan: Justice Scalia Restricts Environmental Standing to Constrain the Courts, 20 ENVTL. L. REP. 10,557, 10,566 (1990).

316. See Sheldon, supra note 315 , at 10,565 (concluding that the case will create "a proliferation of lawsuits" and will result in "[d]isconnected [judicial] review of individual decisions . . . likely to produce inconsistent legal results [that] will impact an overall program very little").

317. Sheldon notes that National Wildlife Federation will have a disproportionate impact on environmental plaintiffs who "assert widely shared interest and challenge governmental actions with widely felt impacts." Id.

318. Sierra Club v. United States Forest Serv., 843 F.2d 1190, 1193 (9th Cir. 1988) (quoting Foundation for N. Am. Wild Sheep v. United States Dep't of Agric., 681 F.2d 1172, 1177-78 (9th Cir. 1982)); see also Missouri Coalition for the Env't v. Corps of Eng'rs, 866 F.2d 1025, 1032 (8th Cir. 1989) ("The initial burden of proof is upon the challenging party to demonstrate that there were facts omitted from the administrative record which, if true, would show that the permitted project could have a substantial impact on the environment."), cert. denied, 493 U.S. 820 (1989); Louisiana v. Lee, 758 F.2d 1081, 1084 (5th Cir. 1985) (claiming that plaintiffs must prove that "the quality of the human environment may be significantly degraded"), cert. denied 475 U.S. 1044 (1986).

319. Some courts have held that the rationale for a minimal burden is linked to the importance that Congress has placed on NEPA and EISs. See, e.g., Minnesota Pub. Interest Research Group v. Butz, 498 F.2d 1314, 1320 (8th Cir. 1974) (employing the minimal burden since "[a]n initial decision 
for plaintiffs. The technical nature of the issue may require plaintiffs to present highly detailed and persuasive evidence on the nature of the impacts. Courts will frequently defer to the expertise of the agency. ${ }^{320}$ Even if such deference is not given, plaintiffs' persuasiveness may be restricted by the fact that courts often refuse to resolve "scientific disagreement among experts." ${ }^{321}$

As for proof that an EIS was inadequate, the burden for plaintiffs becoines even greater. "[T] he plaintiffs are required to establish that the EIS is inadequate. More than an allegation of deficiencies is necessary; the plaintiffs must prove the essential allegations of their complaint by a preponderance of the evidence."322 A stringent standard also may be applied to plaintiffs who clain that the agency failed to consider reasonable alternatives. ${ }^{323}$

\section{Conclusion}

Winning the right to participate in administrative decisions has been seen as a great boon to environmentalist organizations. ${ }^{324}$ To the extent that a record rule encourages early and thorough participation by interested parties, it would seem to promote more legitinate and thoughtful agency decisions. This scenario assuines, however, that interested parties have the resources to perforn more extensive analyses and to participate fully in the early administrative planning stages. Environmental organizations have neither the resources nor the expertise to build records adequate for litigation in each administrative proceeding in which they

not to prepare an EIS precludes the full consideration directed by Congress"); Mont Vernon Preservation Soc'y v. Clements, 415 F. Supp. 141, 146 (D.N.H. 1976) ("The determination that an EIS is not required must be closely scrutinized for, in failing to prepare an EIS, the intensive environmental examination directed by Congress in its passage of NEPA is avoided.").

320. See supra note 199.

321. Sierra Club v. Froehlke, 816 F.2d 205, 214 (5th Cir. 1987); see also Izaak Walton League of Am. v. Marsh, 655 F.2d 346, 372 (D.C. Cir. 1981) (holding that courts "should not attempt to resolve conflicting scientific opinions"), cert. denied, 454 U.S. 1092 (1981).

322. Louisiana Wildlife Fed'n v. York, 761 F.2d 1044, 1054 (5th Cir. 1985); see also North Buekhead Civic Ass'n v. Skinner, 903 F.2d 1533, 1546 (11th Cir. 1990); Sierra Club v. Callaway, 499 F.2d 982 (5th Cir. 1974). However, some courts have employed a different standard, while other courts have chosen not to designate any standard. Compare Hart \& Miller Islands Area Envtl. Group v. Corps of Eng'rs, 505 F. Supp. 732, 761 (D. Md. 1980) (requiring showing of "substantial and dependable evidence") with Sierra Club v. Froehlke, 816 F.2d 205, 213 (5th Cir. 1987) (placing the burden of proof on the Sierra Club but not designating a specific standard of proof); and Monroe County Conservation Council, Inc. v. Adams, 566 F.2d 419, 422 (2d Cir. 1977) (same), cert. denied, 435 U.S. 1006 (1978).

323. See Roosevelt Campobello Int'l Park Comm'n v. EPA, 684 F.2d 1034, 1047 (1st Cir. 1982) (a complainant must present more than a "facially plausible suggestion: rather, [the plaintiff] must offer tangible evidence that an alternative site might offer 'a substantial measure of superiority' as a site" (eitation omitted)).

324. See, e.g., Rosenbaum, supra note 134, at 269 (noting that "generous provision for publie involvement in federal land-use planning has been among the most effective structural means of giving [environmental groups] access and infiuence in the administrative process"). 
participate. If they were forced to assume responsibility for creating a coinprehensive record in each case, outside groups could effectively review a inuch narrower portion of government decisions. Rather than acting as watchdogs to ensure that agencies meet their NEPA obligations, public interest groups would be forced to perform the very task that NEPA has assigned to the government-building a record of significant environmental effects.

The structure of a lawsuit already places significant burdens on plaintiffs, including overcoming finanical hurdles and meeting standing requirements and the burden of proof. These burdens ensure that plaintiffs will raise most major issues before the agency at some point, that parties without a real interest at stake will not bring frivolous claims, and that coinpelling proof will be needed to overturn agency determinations. A stringent application of the record rule is an unnecessary additional burden on outside parties facing derelict admimistrative agencies.

\section{$\mathrm{V}$ \\ The Record Rule OUTSIDE NEPA}

The most thorough study available on the record rule in inforinal agency action concluded that the rule was so riddled with exceptions and so inconsistent witl meaningful judicial review that it might be better to eliminate the rule altogether. ${ }^{325}$ While the researcl in this Comment is too narrow to support such a broad conclusion, it may be useful at this point to examine whether the principles behind the NEPA exception inay be extended to otlier areas of judicial review of administrative actions.

This Coinment advocates an exception to the record rule in NEPA cases on several grounds. First, because NEPA applies to all adıninistrative agencies, claims of agency expertise in most cases are questionable. While NEPA's broad application is unusual, there may be situations where the agency has gone beyond its narrow area of expertise and slould not be afforded the deference inlerent in the record rule. The Endangered Species Act, which requires compliance by all federal agencies, ${ }^{326}$ miglit be an exaniple of such a statute. ${ }^{327}$ Even less deference

325. See Stark \& Wald, supra note 10 , at $358-62$.

326. The Endangered Species Act makes it illegal for any person to "take" a listed species. 16 U.S.C. § 1538(a)(1)(B) (1988) ("Section 9 claim"). The definition of "person" includes federal agencies. Id. § 1532(13). In addition, federal agencies must consult with the Fish and Wildlife Service in order to insure that agency action is not likely to jeopardize the existence of an endangered species or destroy its habitat. Id. $\S 1536$ (a)(2) ("Section 7 claim"). The ESA thus applies to all federal agencies, regardless of their expertise in wildlife management.

327. At least some courts appear to have been willing to allow extra-record evidence in challenges to agency decisions which implicate the Endangered Species Act. See, e.g., Sierra Club v. Yeutter, 926 F.2d 429, 432 (5th Cir. 1991) (district court conducted a four-day trial); Palila v. Hawaii Dep't of Land \& Natural Resources, 649 F. Supp. 1070, 1072 n.3 (D. Haw. 1986) (allowing numerous experts on trees, sheep, and birds to testify at trial). In addition, several courts have 
should be accorded where the agency may have incentives to create an inadequate or minimal record.

Second, because NEPA is a procedural statute, which places no substantive limits on the agency's final decision to proceed with a proposed project, judicial deference to agency imdependence is less warranted. Thus, where an agency retains such ultinate discretion to proceed with its action, courts should be less concerned about treading on the rights of the agency and hence more willing to go outside the record to determine whether the agency's procedural obligations have been inet.

Third, because NEPA decisions are informal, the courts cannot rely on public comments at the administrative level to remedy defects in agency analysis. While the Supreine Court has held that review of even informal decisions should generally focus on the administrative record, ${ }^{328}$ where agency decisions are highly technical and agency expertise suspect, this precept should be reexamined. Even where agency expertise may be presumed, there is a strong arguinent that courts sliould accept extra-record evidence where a party asserts that an agency iguored relevant factors. ${ }^{329}$

Courts should also review the procedures which the agency has used to involve the public in its decisionmaking process. Where the agency provides procedures that facilitate an interchange of ideas and encourage in-depth participation by outside groups, the argument for allowing extra-record evidence is less compelling. For example, an agency might conduct formal or quasi-formal proceedings, or establish an appeal process, to which all interested parties are given notice and in which they are allowed to participate. Such ineasures have high adininistrative costs, but may demonstrate the kind of good faith evidentiary investigation which the court in Cronin believed necessary. ${ }^{330}$

Finally, with statutes such as NEPA, where the agency has an affirmative duty to investigate and inake findings, the duty should not be passed from the shoulders of the agency to petitioners at the administrative level. This is particularly true where the decision will

reviewed the agency's determination de novo rather than under an arbitrary and capricious standard of review. See, e.g., Sierra Club v. Yeutter, 926 F.2d at $438 \&$ n.13 (noting that de novo review of section 9 claims-determining whether a federal agency has "taken" an endangered species-may be appropriate since such review does not implicate the expertise of the Fish and Wildlife Service); Swan View Coalition, Inc. v. Turner, No. 89-121, slip op. at 37 (D. Mont. Dec. 7, 1992) (reviewing section 9 claims under a de novo standard).

328. See supra text accompanying notes 77-86.

329. See supra Section III.A. The Ninth Circuit has adopted such a standard in reviewing administrative action. See Asarco, Inc. v. EPA, 616 F.2d 1153, 1160 (9th Cir. 1980) (noting that a court may "consider [extra-record] evidence relevant to the substantive merits of the agency action only for background information, ... or for the limited purposes of ascertaining whether the agency considered all the relevant factors or fully explicated its course of conduct or grounds of decision").

330. See Cronin v. United States Dep't of Agric., 919 F.2d 439, 444 (7th Cir. 1990). 
have wide and diffuse public impacts, as NEPA decisions often do. ${ }^{331}$ But even where private parties have statutory duties, a strict record rule can be unduly harsh and unfair. ${ }^{332}$ Plaintiffs should, for example, have an opportunity to show that the agency considered, but oimitted fron the official administrative record, materials that were unfavorable to its position; ${ }^{333}$ or that new evidence has arisen which challenges the agency's findings; $;^{334}$ or that the agency's failure to act in a given situation was illegal. ${ }^{335}$ Lastly, issues which are, by their nature, before courts but never directly before agencies, must be adjudicated judicially and caimot be limited to the administrative record. Examples of such issues include plaintiffs' standing or the appropriateness of injunctive rehef. ${ }^{336}$

\section{CONCLUSION}

Reviewing agency action based on the information that was before the agency at the time it made its decision makes sense where agency proceedings are quasi-judicial or quasi-legislative in nature and intended prinarily to present a forum for public imput. NEPA decisions are not made in such a context. Rather than acting as neutral arbiters, agency officials performing mandatory environmental review under NEPA must initiate mvestigation into the foreseeable environmental impacts of their proposed projects and present a reasonable set of alternatives. A court's judgment on whether or not the agency has met this basic duty should not depend on the quality and persuasiveness of the information that outside groups submit to the agency during informal comment procedures.

Rather, the courts should allow the use of extra-record evidence to prove that agencies have failed to prepare adequately the "detailed dis-

331. Stewart notes that the diffuse nature of environmental harm often leads to a delayed awareness of injury. This may reduce representation at both the administrative and the judicial levels:

Broad participation rights do not, by any means, ensure that all relevant interests will be represented before the agencies. Representation of these interests is especially unlikely in what may be a frequent situation in administrative law-where the impact of a decision is widely diffused so that no single individual is harmed sufficiently to have an incentive to undertake litigation, and where high transaction costs and the collective nature of the benefit sought preclude a joint litigating effort, even though the aggregate stake of the affected individuals would justify it.

Stewart, supra note 1, at 1763.

332. See Stark \& Wald, supra note 10.

333. See id. at 347-48.

334. See id. at 349-50.

335. See id. at $350-51$.

336. See id. at 353-54; Natural Resources Defense Council v. Duvall, 777 F. Supp. 1533, 1534 n.1 (E.D. Cal. 1991) (evidence necessary to prove standing need not be part of the administrative record); Don't Ruin Our Park v. Stone, 749 F. Supp. 1388, 1392 (M.D. Pa. 1990) (applying the record rule, but allowing evidence pertaining to a preliminary injunction insofar as it addresses the likelihood of immediate or irreparable harm if an injunction was not issued and the likelihood that public interest would be adversely affected by an injunction), aff'd, 931 F.2d 49 (1991). 
cussion" of environmental impacts required by NEPA. Diminishing plaintiffs' ability to prove their case in court by restrictimg them to the administrative record demands a rationale more compelhing than bureaucratic efficiency and the need to ensure agency independence. The advantages of bureaucratic efficiency inust be weighed against the risks of agency lawlessness. And the threats to agency independence are ininimal in NEPA cases, where the ultimate decision of whether or not to continue with a project is not subject to judicial review, and reliance on agency expertise inay be misplaced.

Early and thorough contributions from outside groups help ensure the integrity of the environmental review process. But it is the agencies' duty to educate the public and the public should not be accountable for failing to bring critical environmental issues to the attention of the agencies. 